\title{
INTRODUCTORY NOTE TO PROSECUTOR V. JEAN-PIERRE BEMBA GOMBO: JUDGMENT ON THE APPEAL OF MR. JEAN-PIERRE BEMBA GOMBO AGAINST TRIAL CHAMBER III'S “JUDGMENT PURSUANT TO ARTICLE 74 OF THE STATUTE” (INT'L CRIM. CT.) BY JOSEPH POWDERLY*
}

[June 8, 2018]

\section{Introduction}

On June 8, 2018, the Appeals Chamber of the International Criminal Court (ICC) delivered its eagerly anticipated judgment on the appeal of Jean-Pierre Bemba Gombo against his conviction by Trial Chamber III in March 2016 for war crimes (murder, rape, and pillage) and crimes against humanity (murder and rape). ${ }^{1}$ Bemba's conviction was notable for the variety of "firsts" it gave rise to for the ICC. As a former vice-president of the transitional government of the Democratic Republic of the Congo (DRC) and president of the Mouvement de libération du Congo (MLC), he became the most senior leader to be successfully convicted by the ICC. His conviction was the first in which an individual was found responsible for the commission of crimes pursuant to command responsibility under Article 28 of the Rome Statute. Of particular significance was the fact that this was the first conviction at the ICC for acts of rape and sexual violence committed against women and men. Finally, this was the first case in the history of international criminal law where members of the defense team were arrested, tried, and convicted of crimes against the administration of justice during the course of the trial. ${ }^{2}$ The trial judgment was heralded as "a turning point in the ICC's history" following the debacles in the Lubanga, Katanga, Chui, and Kenya cases. ${ }^{3}$ However, we now have a new addition to the list of firsts: with the Appeals Chamber's majority judgment (decided 3-2), Bemba becomes the first accused to have his conviction overturned in full.

Appellate acquittals, particularly in the international criminal context, are rarely free from controversy, and the primary source of contention often stems not from the fact of the acquittal, but rather from the reasoning underpinning the decision. The Gotovina and Perisić cases at the International Criminal Tribunal for the former Yugoslavia (ICTY) are obvious examples of appellate acquittals that divided the bench (decided 3-2 and 4-1 respectively) and drew widespread criticism from commentators unpersuaded by the ratio relied on by the majority in each instance. There is every reason to conclude that the Bemba appeal judgment sits alongside Gotovina and Perisić as an appellate anomaly. The judgment aberrates from established jurisprudence, policy, and principle on a host of issues that will no doubt be the subject of careful scholarly scrutiny. This short Introductory Note reflects on the three issues on which the judgment of the majority turned, namely: (1) the standard of appellate review; (2) whether Bemba's conviction exceeded the scope of the charges; and (3) the majority's findings with respect to requirements of command responsibility. However, before advancing further it is worth gaining some appreciation of just how divided the Chamber was on almost every aspect of the appeal.

\section{A Chamber Divided}

Bemba raised six main grounds of appeal, arguing that the trial judgment was "littered with mistakes" and that "[i]ts very fabric, namely the connection between its factual findings and the allegedly supporting evidence [was] negligently woven." 4 The majority_Judge Eboe-Osuji (presiding), Judge Van den Wyngaert, and Judge Morrisondetermined that Ground 2, which argued that the facts and circumstances on which Bemba was convicted exceeded the charges, and part of Ground 3, relating to whether or not Bemba had taken all necessary and reasonable measures, were dispositive of the appeal.

The narrow boundaries of the eighty-page majority judgment are a primary indication of the sparsity of agreement between the judges on important questions of law and fact; only a bare majority were able to agree on only a handful of issues. When consideration is given to the separate and dissenting opinions appended to the majority judgment (i. e., the concurring separate opinion of Judge Eboe-Osuji, the joint separate opinion of Judge Van den Wyngaert and Judge Morrison, and the joint dissenting opinion of Judge Monageng and Judge Hofmański), it is beyond question 
that this was a fundamentally divided chamber. The separate and dissenting opinions offer various reflections on nondeterminative issues within the case and more generally. Reading the various opinions, it is often difficult to discern the full extent of the common ground shared by each of the judges on key points of law. In the end, the judgment poses more questions than it answers.

The gulf between the majority and the minority could not be greater. In their joint separate opinion, Judge Van den Wyngaert and Judge Morrison express the view that the division "is not just a matter of difference of opinion, but appears to be a fundamental difference in the way we look at our mandates as international judges."

We seem to start from different premises, both in terms of how the law should be interpreted and applied and in terms of how we conceive of our role as judges. While we do not presume to speak for our colleagues, it is probably fair to say that we attach more importance to the strict application of the burden and standard of proof. We also seem to put more emphasis on compliance with due process norms that are essential to protecting the rights of the accused in an adversarial setting. ${ }^{6}$

This statement truly lifts the veil on the depth of disagreement within the chamber. For the majority, this judgment was as much about the very nature and function of appellate adjudication as it was about Bemba's liberty. The majority purport to execute their function free of sentiment or the dilution of principle; in their view they are merely upholding "the highest standards of quality, precision and accuracy." It is regrettable, however, that adherence to principles of certainty, consistency, and predictability was not given equal attention. This is most clearly illustrated with respect to the majority's unilateral reframing of the standard of appellate review applicable to alleged errors of fact.

\section{The Death of Appellate Deference on Issues of Fact}

Few would have predicted that the Chamber would depart from the well-established standard of appellate review for factual errors when deciding Bemba's appeal, despite the Chamber inviting the parties to address that issue (among others) in an oral hearing on November $27,2017 .{ }^{8}$ Over the years, the Appeals Chamber has consistently determined that, in relation to alleged errors of fact, "it will interfere only in the case where it cannot discern how the [Trial] Chamber's conclusion could have reasonably been reached from the evidence before it." "In light of the Trial Chamber's firsthand receipt and evaluation of the evidence, they are to be afforded a margin of deference with respect to their findings of fact.

The purpose of appellate review is not to evaluate the evidence de novo, but rather to determine whether a reasonable trier of fact could have reached the same conclusion as the Trial Chamber; it is exclusively corrective. Despite the stability of this precedential standard and its provenance in the jurisprudence of the ad hoc tribunals, the majority chose to follow a different path. In their view, "[t]he Appeals Chamber . . . may interfere with the factual findings of the first-instance chamber whenever the failure to interfere may occasion a miscarriage of justice, and not 'only in the case where [the Appeals Chamber] cannot discern how the Chamber's conclusion could have reasonably been reached from the evidence before it." ${ }^{\prime 10}$ This deviation from precedent is not accompanied by supporting reasoning; it is entirely declarative. The amended standard effectively extinguishes the notion of appellate deference, which, the majority is careful to note, is not expressly provided for in the Rome Statute.

In essence, it dispenses with the established reasonableness test and replaces it with a significantly higher "beyond reasonable doubt" standard, thereby potentially conflating the standard of review with the standard of proof. ${ }^{11}$ While the majority state that applying their preferred standard does not entail a de novo review, it is hard to see how that could be avoided. The minority strongly criticize the majority standard, effectively labeling it as arbitrary and against basic principles of legal certainty and predictability. It is impossible to foresee whether this new standard will become the norm or whether the Chamber will revert to the conventional standard at the next available opportunity.

\section{Raising the Bar with Respect to the Specificity and Evidentiary Basis of Charges}

On the second ground of appeal, the majority determined that specific criminal acts of rape, murder, and pillage, which were added to the prosecution case after the Confirmation of Charges decision, could not form part of Bemba's conviction, because they "did not form part of the "facts and circumstances described in the charges.",12 
The Amended Document Containing the Charges (DCC) and the Confirmation of Charges decision provided for the categories of crimes with which Bemba was charged. The charges were couched in nonexhaustive terms ("include, but are not limited to") and were alleged to have been committed within a specified temporal and geographic framework (on the territory of the Central African Republic (CAR) from October 26, 2002 to March 15, 2003).

The majority determined that this description was 'too broad to amount to a meaningful 'description' of the Charges against Mr. Bemba in terms of article 74(2) of the Statute,"13 and that his conviction should be limited only to those specific criminal acts expressly enumerated in the Amended DCC and the Confirmation of Charges Decision. As a consequence, the majority concluded that Bemba's conviction only encompassed one murder, twenty acts of rape, and five acts of pillage. In doing so, they expunged his conviction for an additional eighteen acts of murder, rape, and pillage.

The majority's reasoning raises the bar on what is expected of the Office of the Prosecutor (OTP) in terms of the evidentiary specificity of charges at the pre-trial stage of proceedings. It essentially means that the OTP must adduce all evidence relating to individual criminal acts at the Confirmation of Charges phase and should not expect additional evidence submitted thereafter to go toward conviction. The Confirmation of Charges decision is rightly viewed as laying down the parameters of the case; however, the majority's exacting expectations elevate even further the significance of the pre-trial phase, to the extent that it now dictates in detailed terms the entire evidentiary scope of the trial.

In the view of the minority, the Pre-Trial Chamber is tasked with determining "whether there is a case to be tried ... and not with confirming or crystallising the totality of the factual allegations underpinning these charges for the purposes of the trial." ${ }^{14}$ There are countless circumstances in which evidence of specific criminal acts may only come to light after the confirmation phase; perhaps owing to issues of cooperation or the reluctance of victims and witnesses to cooperate without assurances that a trial will actually take place. The strict requirements of Article 61(9) dictate that once the trial has begun, the charges cannot be amended - a point Judge Eboe-Osuji attempts, unpersuasively, to refute. ${ }^{15}$ In circumstances where evidence comes to light only after the commencement of the trial, what is to be done? The Bemba judgment offers no guidance.

\section{Command Responsibility: Assessing Necessary and Reasonable Measures}

The impact of the majority's reformulation of the standard of appellate review for factual errors is immediately evident in its consideration of Ground 3, relating to Bemba's responsibility as a commander. The Trial Chamber had determined that Bemba had failed to take all necessary and reasonable measures to prevent, repress, or punish the crimes committed by members of the MLC. It found that the measures Bemba did take were limited in mandate, disingenuous, and "primarily motivated by [a] desire to counter public allegations and rehabilitate the public image of the MLC."16 The trial judgment reflected on six hypothetical measures Bemba could have undertaken to prevent or repress crimes, including the withdrawal of MLC troops from CAR. The majority determined that the Trial Chamber's conclusions were unreasonable and were "tainted by serious errors." ${ }^{17}$ In arriving at this conclusion and consequently overturning Bemba's conviction, the majority offered some intriguing insights into their particular conception of "necessary and reasonable measures" and what can be expected of a commander in Bemba's position.

Some aspects of the majority's reasoning are inconsistent with established jurisprudence on the law of command responsibility. First and foremost, the majority held that consideration must be given to what can be reasonably expected of a commander who is geographically remote from the troops under their command. Miles Jackson has pointed out that judges have sometimes invoked remoteness in situations where they feel that the threshold for criminal responsibility is too exacting. ${ }^{18}$ The reasoning of the majority is neither clear nor exhaustive, but it seems to suggest that a remote commander will be held to a lower standard than that of a nonremote commander. In their view, "the Trial Chamber paid insufficient attention to the fact that the MLC troops were operating in a foreign country with the attendant difficulties on Mr. Bemba's ability, as a remote commander, to take measures." 19 It is not immediately clear whether the majority treat remoteness as a relevant consideration in the factual evaluation of the measures taken, or consider it to constitute a legal distinction within the law of command responsibility. Looking to Judge Eboe-Osuji's separate opinion and the dissent, it can be said with some confidence that at least 
three judges were of the opinion that it is simply a part of the factual evaluation. Therefore, as Jackson has pointed out, "Bemba does not stand for the proposition that we are now faced with an additional distinction in the law of command responsibility" between remote and nonremote commanders. ${ }^{20}$

In addition to their critique regarding the failure to give due consideration to Bemba's remoteness, the majority criticized the Trial Chamber for what they viewed as their inappropriate preoccupation with Bemba's potential motives in instituting certain measures. In the view of the majority, this preoccupation "coloured [the Trial Chamber's] entire assessment of the measures he took." ${ }^{21}$ The judges of the majority asserted that military commanders were entitled to engage in a cost/benefit analysis when fulfilling their duty to take necessary and reasonable measures to prevent or punish crimes, including evaluating what action would cause the least disruption to military operations ${ }^{22}$ or would "accomplish additional or extraneous purposes, such as protecting the public image of [their] forces." 23

The Trial Chamber's discussion of what measures Bemba could have taken was deemed to be "unhelpful and problematic." 24 Instead of dealing with hypotheticals, the Chamber should have identified what Bemba could or should have done in concreto. ${ }^{25}$ In light of the Trial Chamber's failure to take Bemba's remoteness into account and its ostensibly inappropriate focus on his motivations, the majority conducted its own assessment of the measures taken and concluded that they were consistent with the requirements of Article 28. However, significantly, the majority made no effort to determine whether each of the measures taken met the "necessary and reasonable measures" standard for each of the specific crimes. This is particularly significant with regards to the documented acts of rape, which were not the focus of any of the measures taken; neither the Mondonga Inquiry nor the Zongo Commission investigated allegations of rape. The only action Bemba took with regards to allegations of rape was to refute them in a letter to the president of FIDH. Irrespective of whether one concludes that the measures taken were necessary and reasonable to prevent, repress, or punish acts of murder and pillage, they were demonstrably inadequate with regards to allegations of rape against the MLC.

\section{The Fallout}

The fallout from the judgment continues to be felt inside and outside of the Court. In the immediate aftermath, Chief Prosecutor Fatou Bensouda took the unprecedented step of issuing a statement expressing her Office's concerns with respect to the change in the standard of appellate review and the level of evidentiary detail required of the charges. ${ }^{26}$ This in turn instigated a response from ICC President Judge Eboe-Osuji, reminding the OTP of the principle of judicial independence and the solemn declaration undertaken by all judges to execute their functions honorably, faithfully, impartially, and conscientiously. ${ }^{27}$ Numerous NGOs expressed their concerns in terms of what this might mean for the future of the institution, with Amnesty International taking the outspoken position that criticism of the judgment should not be to the detriment of meaningful introspection within the OTP.

It may be some time before the Appeals Chamber has another chance to address some of the issues that arose in the judgment, particularly relating to the standard of appellate review for errors of fact. At the time of writing, there is no appeal against a trial judgment pending before the Chamber. The next obvious opportunity is likely to be in the Ntaganda case, whose Trial Chamber is currently deliberating on its judgment. Only then will we be able to determine the true legacy of the Bemba appeal judgment, whether as an aberration or a watershed.

\section{ENDNOTES}

1 Prosecutor v. Bemba, ICC-01/05-01/08 A, Judgment on the Appeal of Mr. Jean-Pierre Bemba Gombo Against Trial Chamber III's "Judgment Pursuant to Article 74 of the Statute" (Jun. 8, 2018) [hereinafter Bemba Appeal Judgment].

2 Prosecutor v. Bemba, ICC-01/05-01/08, Judgment Pursuant to Article 74 of the Statute (Mar. 21, 2016). See also Prosecutor v. Bemba, ICC-01/05-01/08-3434-Red, Public Redacted Version of Appellant's Document in Support of the Appeal, I 1 (Sep. 28, 2016).
3 Yvonne McDermott, Prosecutor v. Bemba. Case N. ICC-01/ 05-01/08. Judgment Pursuant to Article 74 of the Statute, 110 AJIL 526, 530 (2017).

4 Prosecutor v. Bemba, ICC-01/05-01/08-3434-Red, Public Redacted Version of Appellant's Document in Support of the Appeal, 97 (Sep. 29, 2016).

5 Bemba Appeal Judgment, supra note 1 (separate opinion by Van den Wyngaert, C., and Morrison, H.).

$6 \quad I d$. 
7

Id. ๆ 5.

8 Prosecutor v. Bemba, ICC-01/05-01/08-3579, Order in Relation to the Conduct of the Hearing Before the Appeals Chamber, 3 (Nov. 27, 2017).

9 Prosecutor v. Dyilo, ICC-01/04-01/06-3121-Red, Judgment on the Appeal of Mr Thomas Lubanga Dyilo Against His Conviction, ๆ 21 (Dec. 1, 2014).

10 Bemba Appeal Judgment, supra note 1, ๆ 40.

11 Fatou Bensouda, Statement of ICC Prosecutor, Fatou Besouda, on the Recent Judgment of the ICC Appeals Chamber Acquitting Mr Jean-Pierre Bemba Gombo, InT'L CRIM. CT. (Jun. 13, 2018), https://www.icc-cpi.int/Pages/ item.aspx?name=180613-OTP-stat.

12 Bemba Appeal Judgment, supra note 1, ๆ 115.

13 Id. 1110

$14 I d$. 21 (dissenting opinion of Monageng, S. M., and Hofmański, P.).

15 Id. ๆๆ $118-50$.
16 Id. 19 7 727-28.

17 Id. 166.

18 Miles Jackson, Geographical Remoteness in Bemba, EJIL: TALK! (July 30, 2018), https://www.ejiltalk.org/geographicalremoteness-in-bemba/.

19 Bemba Appeal Judgment, supra note 1, \ 171.

20 See Jackson, supra note 18.

21 Bemba Appeal Judgment, supra note 1, 178.

$22 \quad I d .9170$.

23 Id. 9173.

$24 \quad I d .9170$.

25 Id.

26 Bensouda, supra note 11.

27 Chile Eboe-Osuji, Statement of the President of the Court in Relation to the Case of Mr Jean-Pierre Bemba Gombo, INT'L CRIM. CT. (Jun. 14, 2018), https://www.icc-cpi.int/ Pages/item.aspx?name=180614-pres-stat. 
PROSECUTOR V. JEAN-PIERRE BEMBA GOMBO: JUDGMENT ON THE APPEAL OF MR. JEAN-PIERRE BEMBA GOMBO AGAINST TRIAL CHAMBER III'S "JUDGMENT PURSUANT TO ARTICLE 74 OF THE STATUTE” (INT'L CRIM. CT.)*

[June 8, 2018]

Cour

Pénale

Internationale

\section{International}

Criminal

Court

Original: English

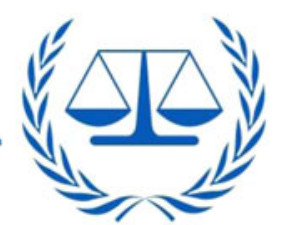

No. ICC-01/05-01/08 A

Date: 8 June 2018

THE APPEALS CHAMBER

Before: $\quad$ Judge Christine Van den Wyngaert, Presiding Judge Judge Chile Eboe-Osuji

Judge Sanji Mmasenono Monageng

Judge Howard Morrison

Judge Piotr Hofmański

SITUATION IN THE CENTRAL AFRICAN REPUBLIC

IN THE CASE OF

THE PROSECUTOR v. JEAN-PIERRE BEMBA GOMBO

Public document

Judgment

on the appeal of Mr Jean-Pierre Bemba Gombo against Trial Chamber III's

"Judgment pursuant to Article 74 of the Statute" 
Judgment to be notified in accordance with regulation 31 of the Regulations of the Court to:

The Office of the Prosecutor

Ms Fatou Bensouda

Ms Helen Brady

Legal Representative of Victims

Ms Marie-Edith Douzima-Lawson
Counsel for the Defence

Mr Peter Haynes

Ms Kate Gibson

\section{REGISTRY}

Registrar

Mr Peter Lewis 


\section{TABLE OF CONTENTS}

JUDGMENT

I. KEY FINDINGS

II. PROCEDURAL HISTORY

III. INTRODUCTION

IV. STANDARD OF REVIEW

A. Errors of law

B. Factual errors

C. Procedural errors

D. Other grounds alleging unfairness

E. Substantiation of arguments

F. Degree of appellate deference to be accorded to the factual findings of the Trial Chamber in the present case $\ldots \ldots \ldots \ldots \ldots \ldots \ldots \ldots$

V.

A. Preliminary issues: Additional Evidence Application and Prosecutor's

Request to File an Additional Authority

B. Second ground of appeal: "The conviction exceeded the charges"

1. Relevant procedural background $\ldots \ldots \ldots \ldots \ldots \ldots \ldots$

2. Submissions of the parties and participants

3. Determination by the Appeals Chamber ...............

(a) Scope of the Conviction Decision

(b) Whether the Conviction Decision exceeded the scope of the charges

(c) Conclusion

C. Third ground of appeal: Command Responsibility: Mr Bemba took all necessary and reasonable measures

1. Relevant Part of the Impugned Decision

2. Submissions of the parties and participants

(a) The Trial Chamber failed to assess Mr Bemba's conduct against the correct legal standard . . . . . . . . . .

(b) The Trial Chamber misappreciated the limitations on the MLC's jurisdiction and competence to investigate .....

(c) The Trial Chamber ignored that Mr Bemba asked the CAR Prime Minister to investigate the allegation .........

(d) The Trial Chamber erred in taking into account irrelevant considerations $\ldots \ldots \ldots \ldots \ldots \ldots \ldots \ldots \ldots$

(e) The findings on measures taken are unreasonable, misstate the evidence and ignore relevant evidence .........

3. Determination by the Appeals Chamber .............

\section{APPROPRIATE RELIEF}

[ILM page 1039]

[ILM page 1039]

[ILM page 1040]

[ILM page 1041]

[ILM page 1042]

[ILM page 1042]

[ILM page 1042]

[ILM page 1044]

[ILM page 1045]

[ILM page 1046]

[ILM page 1047]

[ILM page 1047]

[ILM page 1047]

[ILM page 1047]

[ILM page 1048]

[ILM page 1049]

[ILM page 1052]

[ILM page 1052]

[ILM page 1053]

[ILM page 1055]

[ILM page 1057]

[ILM page 1057]

[ILM page 1059]

[ILM page 1059]

[ILM page 1061]

[ILM page 1062]

[ILM page 1062]

[ILM page 1064]

[ILM page 1065]

[ILM page 1071] 
The Appeals Chamber of the International Criminal Court, In the appeal of Mr Jean-Pierre Bemba Gombo against the decision of Trial Chamber III entitled "Judgment pursuant to Article 74 of the Statute" of 21 March 2016 (ICC-01/05-01/08-3343),

After deliberation,

By majority, Judge Monageng and Judge Hofmański dissenting,

Delivers the following

\section{JUDGMENT}

1) The "Judgment pursuant to Article 74 of the Statute" is reversed.

2) The Appeals Chamber declares that the crimes listed in paragraph 116 of this judgment were not within the facts and circumstances described in the charges and that the Trial Chamber, therefore, could not enter a verdict thereon. The proceedings with respect to these criminal acts are discontinued.

3) Mr Bemba is acquitted of all remaining charges brought against him in the present case.

4) The Appeals Chamber declares that there is no reason to continue Mr Bemba's detention for the purposes of the present case.

5) The "Defence application to present additional evidence in the appeal against the Judgment pursuant to Article 74 of the Statute, ICC-01/05-01/08-3343" is dismissed.

6) The "Prosecution's Request for Leave to Present Additional Authority" is rejected.

\section{REASONS}

1. These are the dispositive reasons of the Appeals Chamber, by majority. Judge Eboe-Osuji concurs, as part of the majority, with the essence of these dispositive reasons and the outcome. Judge Monageng and Judge Hofmański disagree with the reasons and the outcome.

\section{KEY FINDINGS}

2. It is the responsibility of the Appeals Chamber to assess whether or not the trial chamber applied the standard of proof correctly. The accused does not have to prove that the trial chamber made a factual error. It suffices for him or her to identify sources of doubt about the accuracy of the trial chamber's findings to oblige the Appeals Chamber to independently review the trial chamber's reasoning on the basis of the evidence that was available to it.

3. The Appeals Chamber must be satisfied that factual findings that are made beyond reasonable doubt are clear and unassailable, both in terms of evidence and rationale. Accordingly, when the Appeals Chamber is able to identify findings that can reasonably be called into doubt, it must overturn them.

4. Simply listing the categories of crimes with which a person is to be charged or stating, in broad general terms, the temporal and geographical parameters of the charge is not sufficient to comply with the requirements of regulation 52 (b) of the Regulations of the Court and does not allow for a meaningful application of article 74 (2) of the Statute.

5. The scope of the duty to take "all necessary and reasonable measures" is intrinsically connected to the extent of a commander's material ability to prevent or repress the commission of crimes or to submit the matter to the competent authorities for investigation and prosecution. Indeed, a commander cannot be blamed for not having done something he or she had no power to do.

6. An assessment of whether a commander took all "necessary and reasonable measures" must be based on considerations of what crimes the commander knew or should have known about and at what point in time. 
7. Juxtaposing the fact that certain crimes were committed by the subordinates of a commander with a list of measures which the commander could hypothetically have taken does not, in and of itself, show that the commander acted unreasonably at the time. The Trial Chamber must specifically identify what a commander should have done in concreto.

8. It is not the case that a commander is required to employ every single conceivable measure within his or her arsenal, irrespective of considerations of proportionality and feasibility. Article 28 only requires commanders to do what is necessary and reasonable under the circumstances.

9. Whilst a commander is required to act in good faith in adopting "necessary and reasonable measures", the fact that a commander was motivated by a desire to preserve the reputation of his or her troops does not intrinsically render the measures he or she adopted any less necessary or reasonable.

10. A finding that the measures deployed by a commander were insufficient to prevent or repress an extended crime wave does not mean that these measures were also insufficient to prevent or repress the limited number of specific crimes for which the commander is ultimately convicted.

11. The accused person must be informed of the factual allegations on the basis of which the Prosecutor seeks to establish that he or she failed as a commander to take "all necessary and reasonable measures" within his or her power to prevent or repress the commission of crimes or to submit the matter to the competent authorities for investigation and prosecution.

\section{PROCEDURAL HISTORY}

12. On 21 March 2016, Trial Chamber convicted Mr Jean-Pierre Bemba Gombo ("Mr Bemba"), pursuant to article 28 (a) of the Statute, of the crimes against humanity of murder and rape and of the war crimes of murder, rape and pillaging committed by troops of the MLC in the CAR in the course of the 2002-2003 CAR Operation. ${ }^{1}$

13. Mr Bemba was President of the MLC, a political party founded by him and based in the northwest of the DRC, and Commander-in-Chief of its military branch, the ALC. ${ }^{2}$ The events giving rise to his conviction and this appeal took place on the territory of the CAR from on or about 26 October 2002 to 15 March 2003, ${ }^{3}$ during an MLC intervention to support Mr Ange-Félix Patassé, the then President of the CAR, in suppressing a rebellion led by General François Bozizé. ${ }^{4}$

14. On 4 April 2016, Mr Bemba filed his notice of an appeal against the Conviction Decision, ${ }^{5}$ and, on 19 September 2016, he filed his appeal brief. ${ }^{6}$

15. On 19 September 2016, Mr Bemba requested the Appeals Chamber to admit 23 documents as additional evidence in the appeal. ${ }^{7}$

16. On 21 November 2016, the Prosecutor filed her responses to the Appeal Brief ${ }^{8}$ and to the Additional Evidence Application. ${ }^{9}$

17. On 9 December 2016, Mr Bemba filed his reply to the Prosecutor's Response to the Additional Evidence Application. $^{10}$

18. On 20 December 2016, Mr Bemba filed his reply to the Response to the Appeal Brief. ${ }^{11}$

19. On 21 December 2016, the Victims filed their observations on the Additional Evidence Application. ${ }^{12}$

20. On 9 January 2017, the Victims filed their observations on the Appeal Brief. ${ }^{13}$

21. On 9 February 2017, Mr Bemba filed his reply to the Victims' Observations. ${ }^{14}$

22. On 30 October 2017, the Appeals Chamber issued an order for submissions on the contextual elements of crimes against humanity. ${ }^{15}$

23. On 7 November 2017, the Appeals Chamber issued a scheduling order for an appeal hearing. ${ }^{16}$

24. On 13 November 2017, Mr Bemba filed his submissions on the contextual elements of crimes against humanity $^{17}$ and, on 27 November 2017, the Prosecutor filed her response to Mr Bemba's submissions. ${ }^{18}$ 
25. On 27 November 2017, the Appeals Chamber issued an order in relation to the conduct of the hearing which it had scheduled, and invited the parties and participants to address the Appeals Chamber during that hearing on issues regarding the standard of review and Mr Bemba's second, third and fourth grounds of appeal. ${ }^{19}$

26. On 4 December 2017, the Victims' Representatives filed their observations on the contextual elements of crimes against humanity ${ }^{20}$ and, on 11 December 2017, Mr Bemba filed his response to those observations. ${ }^{21}$

27. From 9 to 11 January 2018, the Appeals Chamber held a hearing during which the parties and participants made submissions and observations. ${ }^{22}$ During the hearing, the Appeals Chamber invited the parties and participants to submit further written submissions ${ }^{23}$ which they did on 19 January $2018 .^{24}$ During the hearing, Mr Bemba was represented by Mr Peter Haynes, Ms Kate Gibson, Mr Kai Ambos, Mr Michael A. Newton and Ms Leigh Lawrie. The Prosecutor was represented by Ms Helen Brady, Mr Reinhold Gallmetzer, Mr Matthew Cross, Mr Matteo Costi, and Ms Meritxell Regue. The Victims were represented by Ms Marie-Edith Douzima Lawson and Mr Célestin N'Zala. ${ }^{25}$

28. On 13 April 2018, the Prosecutor sought leave to present an additional authority ${ }^{26}$ and, on 20 April 2018, Mr Bemba responded to this request. ${ }^{27}$

\section{INTRODUCTION}

29 Mr Bemba raises six grounds of appeal, each divided into several sub-grounds. They are the following: (i) that this was a mistrial (Ground 1); ${ }^{28}$ (ii) that the conviction exceeded the charges (Ground 2); ${ }^{29}$ (iii) that Mr Bemba is not liable as a superior (Ground 3); ${ }^{30}$ (iv) that the contextual elements were not established (Ground 4); ${ }^{31}$ (v) that the Trial Chamber erred in its approach to identification evidence (Ground 5) ${ }^{32}$ and (vi) that other procedural errors invalidated the conviction (Ground 6). ${ }^{33}$

30 More specifically in relation to the third ground of appeal, Mr Bemba argues that the Trial Chamber erred when it found that he was responsible as a commander pursuant to article 28 (a) of the Statute for crimes MLC troops had committed during the 2002-2003 CAR Operation. Notably, Mr Bemba submits that the Trial Chamber erred in: (i) finding that he had effective control over the MLC troops in the CAR; ${ }^{34}$ (ii) dismissing and ignoring evidence relevant to that question; ${ }^{35}$ (iii) finding that he had actual knowledge of MLC crimes; ${ }^{36}$ (iv) finding that he did not take all necessary and reasonable measures; ${ }^{37}$ and, further, (v) finding that the causation requirement had been established. ${ }^{38}$

31 The Appeals Chamber has held extensive deliberations on each of these grounds and in January 2018 called a hearing to clarify some of the issues with the parties and participants.

32 Judge Van den Wyngaert, Judge Eboe-Osuji and Judge Morrison are of the view that the second ground of appeal and part of the third ground of appeal, namely Mr Bemba's argument that the Trial Chamber erred when it found that he did not take all necessary and reasonable measures to prevent or repress the commission of crimes, are determinative of the outcome of the appeal. As to the remainder of the third ground of appeal, whereas the majority of the Appeals Chamber also has concerns regarding the Trial Chamber's findings relevant to Mr Bemba's effective control and his actual knowledge of crimes committed by MLC troops in the CAR, it has limited its assessment to the Trial Chamber's finding regarding Mr Bemba's purported failure to take all necessary and reasonable measures, given the clear error therein. For the same reasons, the first, fourth, fifth and sixth grounds of appeal are not addressed herein.

33 The reasons of Judge Van den Wyngaert and Judge Morrison as to the conclusion concerning the second ground of appeal and part of the third ground of appeal are set out below. Judge Eboe-Osuji, whilst agreeing in essence with the reasons of Judge Van den Wyngaert and Judge Morrison and with the outcome of the appeal, also sets out his views in respect of those issues in a separate opinion. Judge Van den Wyngaert, Judge EboeOsuji and Judge Morrison address aspects of the remaining grounds of appeal in their separate opinions.

34 Judge Monageng and Judge Hofmański disagree with the standard of review for factual errors and aspects of the substantiation requirement, ${ }^{39}$ and dissent from the majority's determination on the second ground of appeal and on the third ground of appeal, concerning necessary and reasonable measures, for the reasons set out in their 
dissenting opinion. The views of the minority on the first, remainder of the third, fourth, fifth and sixth grounds of appeal are also set out in their dissenting opinion.

\section{STANDARD OF REVIEW}

35 Article 81 (1) (b) of the Statute provides that the convicted person, or the Prosecutor on his or her behalf, may appeal on grounds of a procedural error, error of fact, error of law, or any other ground that affects the fairness or reliability of the proceedings or decision. According to article 83 (2) of the Statute, the Appeals Chamber may intervene only if it "finds that the proceedings appealed from were unfair in a way that affected the reliability of the decision or sentence, or that the decision or sentence appealed from was materially affected by error of fact or law or procedural error". In the view of the Appeals Chamber, this results in the following standard of review for legal, factual and procedural errors, as well as for other grounds affecting the fairness or reliability of the decision.

\section{A. Errors of law}

36. Regarding errors of law, the Appeals Chamber has previously found that it:

[...] will not defer to the Trial Chamber's interpretation of the law. Rather, it will arrive at its own conclusions as to the appropriate law and determine whether or not the Trial Chamber misinterpreted the law. If the Trial Chamber committed such an error, the Appeals Chamber will only intervene if the error materially affected the Impugned Decision.

$[\ldots]$ A judgment is 'materially affected by an error of law' if the Trial Chamber 'would have rendered a judgment that is substantially different from the decision that was affected by the error, if it had not made the error'. [Footnotes omitted]. ${ }^{40}$

37. The Appeals Chamber sees no reason to diverge from this standard, nor has any of the parties or participants invited the Appeals Chamber to do so. Accordingly, it will apply this standard to the present case.

\section{B. Factual errors}

38. It has previously been stated that when a factual error is alleged, the Appeals Chamber's task is to determine whether a reasonable trial chamber could have been satisfied beyond reasonable doubt as to the finding in question, ${ }^{41}$ thereby applying a margin of deference to the factual findings of the trial chamber. However, the Appeals Chamber considers that the idea of a margin of deference to the factual findings of the trial chamber must be approached with extreme caution.

39. With respect to the application of this margin of deference, the Appeals Chamber has previously held that:

[I]t will not interfere with factual findings of the first-instance Chamber unless it is shown that the Chamber committed a clear error, namely, misappreciated the facts, took into account irrelevant facts, or failed to take into account relevant facts. As to the 'misappreciation of facts', the Appeals Chamber has also stated that it 'will not disturb a Pre-Trial or Trial Chamber's evaluation of the facts just because the Appeals Chamber might have come to a different conclusion. It will interfere only in the case where it cannot discern how the Chamber's conclusion could have reasonably been reached from the evidence before it'. ${ }^{42}$

40. The Appeals Chamber is of the opinion that it may interfere with the factual findings of the first-instance chamber whenever the failure to interfere may occasion a miscarriage of justice, and not "only in the case where [the Appeals Chamber] cannot discern how the Chamber's conclusion could have reasonably been reached from the evidence before it". The Appeals Chamber must be careful not to constrain the exercise of its appellate discretion in such a way that it ties its own hands against the interest of justice, particularly in circumstances where the Rome Statute does not provide for the notion of appellate deference or require the Appeals Chamber to apply that particular notion.

41. As previously noted, in assessing alleged errors of fact, the ad hoc tribunals have also applied a standard of reasonableness. ${ }^{43}$ This Appeals Chamber has done the same. However, this standard is not without qualification. 
This Appeals Chamber must ensure that the trial chamber reasonably reached a conviction as to guilt beyond reasonable doubt in accordance with article 66(3) of the Statute.

42. When a factual error is alleged, the Appeals Chamber will not assess the evidence de novo with a view to determining whether it would have reached the same factual conclusion as the trial chamber; in this connection, the Appeals Chamber deems it necessary to clarify that it will determine whether a reasonable trial chamber properly directing itself could have been satisfied beyond reasonable doubt as to the finding in question, based on the evidence that was before it. ${ }^{44}$ In this regard, it must be borne in mind that the trial chamber is required to make findings of fact to the standard of proof of "beyond reasonable doubt" only in relation to those facts that correspond to the elements of the crime and mode of liability of the accused as charged. ${ }^{45}$ It must be stressed in this regard that the trial chamber must have properly directed itself to the applicable standard of proof. In this regard, the Appeals Chamber recalls its finding in the Bemba et al. Appeal Judgment on conviction as to the conditions under which a trial chamber may establish facts on the basis of circumstantial evidence and inferences:

Where a factual finding is based on an inference drawn from circumstantial evidence, the finding is only established beyond reasonable doubt if it was the only reasonable conclusion that could be drawn from the evidence. It is indeed well established that it is not sufficient that a conclusion reached by a trial chamber is merely $a$ reasonable conclusion available from that evidence; the conclusion pointing to the guilt of the accused must be the only reasonable conclusion available. If there is another conclusion reasonably open from the evidence, and which is consistent with the innocence of the accused, he or she must be acquitted. For alleged errors of fact in relation to factual findings that were based on inferences drawn from circumstantial evidence, the Appeals Chamber will therefore, in keeping with the standard of review for factual errors, consider whether no reasonable trier of fact could have concluded that the inference drawn was the only reasonable conclusion that could be drawn from the evidence. [Footnotes omitted.] ${ }^{46}$

43. In determining whether a given factual finding was reasonable, a trial chamber's reasoning in support thereof is of great significance. The Appeals Chamber notes that as put by the Supreme Court Chamber of the ECCC:

[T]he starting point for the Supreme Court Chamber's assessment of the reasonableness of the Trial Chamber's factual findings is the reasoning provided for the factual analysis, as related to the items of evidence in question. In particular when faced with conflicting evidence or evidence of inherently low probative value (such as out-of-court statements or hearsay evidence), it is likely that the Trial Chamber's explanation as to how it reached a given factual conclusion based on the evidence in question will be of great significance for the determination of whether that conclusion was reasonable. As a general rule, where the underlying evidence for a factual conclusion appears on its face weak, more reasoning is required than when there is a sound evidentiary basis. ${ }^{47}$

44. The Appeals Chamber finds this approach persuasive. Thus, when assessing the reasonableness of a factual finding, the Appeals Chamber will have regard not only to the evidence relied upon, but also to the trial chamber's reasoning in analysing it. In particular if the supporting evidence is, on its face, weak, or if there is significant contradictory evidence, deficiencies in the trial chamber's reasoning as to why it found that evidence persuasive may lead the Appeals Chamber to conclude that the finding in question was such that no reasonable trier of fact could have reached. Nevertheless, the emphasis of the Appeals Chamber's assessment is on the substance: whether the evidence was such as to allow a reasonable trial chamber to reach the finding it did beyond reasonable doubt.

45. Ultimately, the Appeals Chamber must be satisfied that factual findings that are made beyond reasonable doubt are clear and unassailable, both in terms of evidence and rationale. Mere preferences or personal impressions of the appellate judges are insufficient to upset the findings of a trial chamber. However, when a reasonable and objective person can articulate serious doubts about the accuracy of a given finding, and is able to support this view with specific arguments, this is a strong indication that the trial chamber may not have respected the standard of proof and, accordingly, that an error of fact may have been made.

46. When the trial chamber is not convinced of guilt beyond reasonable doubt it must refrain from entering a finding. Accordingly, when the Appeals Chamber is able to identify findings that can reasonably be called into 
doubt, it must overturn them. This is not a matter of the Appeals Chamber substituting its own factual findings for those of the trial chamber. It is merely an application of the standard of proof.

\section{Procedural errors}

47. Regarding procedural errors, the Appeals Chamber has found that:

$[A] n$ allegation of a procedural error may be based on events which occurred during the pre-trial and trial proceedings. However, as with errors of law, the Appeals Chamber will only reverse a decision $[\ldots]$ if it is materially affected by the procedural error. In that respect, the appellant needs to demonstrate that, in the absence of the procedural error, the decision would have substantially differed from the one rendered. ${ }^{48}$

48. Having previously found that "procedural errors often relate to alleged errors in a Trial Chamber's exercise of its discretion", 49 the Appeals Chamber has established that:

[...] it will not interfere with the Chamber's exercise of discretion merely because the Appeals Chamber, if it had the power, might have made a different ruling. The Appeals Chamber will only disturb the exercise of a Chamber's discretion where it is shown that an error of law, fact or procedure was made. In this context, the Appeals Chamber has held that it will interfere with a discretionary decision only under limited conditions and has referred to standards of other courts to further elaborate that it will correct an exercise of discretion in the following broad circumstances, namely where (i) it is based upon an erroneous interpretation of the law; (ii) it is based upon a patently incorrect conclusion of fact; or (iii) the decision amounts to an abuse of discretion. Furthermore, once it is established that the discretion was erroneously exercised, the Appeals Chamber has to be satisfied that the improper exercise of discretion materially affected the impugned decision. [Footnotes omitted]. ${ }^{50}$

49. The Appeals Chamber notes that Mr Bemba raises several arguments that allege a lack of or insufficient reasoning in support of factual findings contained in the Conviction Decision; he argues that these deficiencies amount to errors of law and/or fact on the part of the trial chamber. ${ }^{51}$ The Appeals Chamber recalls that article 74 (5) of the Statute requires the trial chamber to provide "a full and reasoned statement of [its] findings on the evidence and conclusions". If a decision under article 74 of the Statute does not completely comply with this requirement, this amounts to a procedural error.

50. In the view of the Appeals Chamber, in interpreting article 74 (5) of the Statute, it is appropriate to have regard to the jurisprudence of the ECtHR, which has underlined the importance of reasoning in allowing the accused person to usefully exercise available rights of appeal; it requires that courts "indicate with sufficient clarity the grounds on which they based their decision". 52 The provision of reasons also enables the Appeals Chamber to clearly understand the factual and legal basis upon which the decision was taken and thereby properly exercise its appellate functions.

51. The Appeals Chamber has previously outlined its considerations regarding the requirement of a reasoned decision in the following terms:

The extent of the reasoning will depend on the circumstances of the case, but it is essential that it indicates with sufficient clarity the basis of the decision. Such reasoning will not necessarily require reciting each and every factor that was before the [...] Chamber to be individually set out, but it must identify which facts it found to be relevant in coming to its conclusion. ${ }^{53}$

52. The Appeals Chamber finds that these considerations also apply, in principle, to decisions on the guilt or innocence of the accused under article 74 of the Statute. It must be clear from the trial chamber's decision which facts it found to have been established beyond reasonable doubt and how it assessed the evidence to reach these factual findings. 
53. To fulfil its obligation to provide a reasoned opinion, a trial chamber is not required to address all the arguments raised by the parties, or every item of evidence relevant to a particular factual finding, provided that it indicates with sufficient clarity the basis for its decision. ${ }^{54}$

54. The Appeals Chamber notes that a trial chamber thus has a degree of discretion as to what to address and what not to address in its reasoning. Not every actual or perceived shortcoming in the reasoning will amount to a breach of article 74 (5) of the Statute. It is also of note that, when determining whether there was a breach of article 74 (5) of the Statute, the Appeals Chamber will assess whether there was reasoning in support of a given factual finding; if particular items of evidence that are, on their face, relevant to the factual finding are not addressed in the reasoning, the Appeals Chamber will have to determine whether they were of such importance that they should have been addressed, lest it becomes impossible to determine - based on the reasoning provided and the evidence in question - how the trial chamber reached the conclusion it did.

55. If a trial chamber's reasoning in relation to a given factual finding does not conform with the principles set out in the preceding paragraphs, this may amount to a procedural error, as the trial chamber's conviction would, in respect of that particular finding, not comply with the requirement in article 74 (5) of the Statute. Such an error has a material effect in terms of article 83 (2) of the Statute because it inhibits the parties from properly mounting an appeal in relation to the factual finding in question and prevents the Appeals Chamber from exercising its appellate review.

56. The appropriate remedy in such a case will depend on the circumstances, in particular the extent of insufficient or lacking reasoning. In particular, in cases where the lack of reasoning is extensive, the Appeals Chamber may decide to order a new trial before a different trial chamber. ${ }^{55}$ Alternatively, it may be appropriate to remand the factual finding to the original trial chamber with the instruction to properly set out its reasoning in support of it and report back to the Appeals Chamber. ${ }^{56}$ Particularly if the original trial chamber is no longer available, the Appeals Chamber may also decide to determine de novo the factual question at hand, analysing the relevant evidence that was before the trial chamber. ${ }^{57}$ If the Appeals Chamber's assessment of this evidence leads it to adopt the same factual finding as that adopted by the trial chamber, the Appeals Chamber will confirm the impugned decision in relation to the factual finding despite the insufficient or lacking reasoning. If, however, the Appeals Chamber, based on its own assessment of the evidence, adopts a factual finding that is different from the one adopted by the trial chamber, the Appeals Chamber will then need to consider the impact, if any, of this new factual finding on the finding as to the guilt or innocence of the accused person.

\section{Other grounds alleging unfairness}

57. The parties to the proceedings have made submissions on the appropriate standard of review and, in particular, the interplay between article 81 (1) (b) (iv) and article 83 (2) of the Statute. ${ }^{58}$ The Appeals Chamber shall now address these issues.

58. Article 81 (1) (b) of the Statute reads in its relevant part:

The convicted person, or the Prosecutor on that person's behalf, may make an appeal on any of the following grounds:

$[\ldots]$

(iv) Any other ground that affects the fairness or reliability of the proceedings or decision.

59. Pursuant to article 83 (2) of the Statute, the Appeals Chamber may reverse or amend the impugned decision, or order a new trial, if it "finds that the proceedings appealed from were unfair in a way that affected the reliability of the decision or sentence". 59

60. Article 81 (1) (b) (iv) of the Statute provides that an appellant may, under this ground, question, on the one hand the fairness of the proceedings or decision or, on the other hand, the reliability of the proceedings or decision. Read on its own, this would suggest, for instance, that an appellant may succeed in an appeal against his or her conviction by demonstrating that there was unfairness, without it having been established that this had any impact on the reliability of the trial chamber's decision under article 74 of the Statute. Yet article 81 (1) (b) (iv) of the Statute must be read in conjunction with article 83 (2) of the Statute, which clarifies that, for the Appeals Chamber to intervene, it 
must be demonstrated that the proceedings were unfair in such a way as to affect the reliability of the decision or sentence.

61. This interpretation was adopted in the Lubanga Appeal Judgment, wherein the Appeals Chamber set out a two-limb enquiry into the allegations of unfairness in the following manner:

In keeping with articles 81 (1) (b) (iv) and 83 (2) of the Statute, these allegations are considered [...] in relation to whether [the convicted person's] rights have been violated and, if so, whether such violations affected the reliability of the Conviction Decision. ${ }^{60}$

62. Seeing no reason to depart from that holding, the Appeals Chamber concludes that a convicted person seeking to appeal his or her conviction on grounds of unfairness is required to set out not only how it was that the proceedings were unfair, but also how this affected the reliability of the conviction decision. Whether any unfairness that is established affects the reliability of the decision is not a question that can be decided in abstracto; it is dependent on the nature of the particular case that is before the Appeals Chamber and must be determined as such. In some cases, a particular breach might be decisive and lead to a reversal of a conviction, whilst in other cases it might be determined that the unfairness can be cured or that the breach does not have an impact on the reliability of the conviction.

\section{E. Substantiation of arguments}

63. Regulation 58 (3) of the Regulations of the Court requires the appellant to refer to "the relevant part of the record or any other document or source of information as regards any factual issue" and "to any relevant article, rule, regulation or other applicable law, and any authority cited in support thereof' as regards any legal issue. It also stipulates that the appellant must identify the finding or ruling challenged in the decision with specific reference to the page and paragraph number. Failure to observe these formal requirements may result in an argument being dismissed in limine.

64. The Appeals Chamber has previously held that, in order to substantiate an argument, "the appellant is required to set out the alleged error and how the alleged error materially affected the impugned decision. If an appellant fails to do so, the Appeals Chamber may dismiss the argument without analysing it in substance". ${ }^{1}$ The Appeals Chamber has found:

Whether an error or the material effect of that error has been sufficiently substantiated will depend on the specific argument raised, including the type of error alleged. With respect to legal errors, the Appeals Chamber, as set out above, 'will arrive at its own conclusions as to the appropriate law and determine whether or not the Trial Chamber misinterpreted the law'. Accordingly, the appellant has to substantiate that the Trial Chamber's interpretation of the law was incorrect; $[\ldots]$ this may be done including by raising arguments that were previously put before the Pre-Trial and/or Trial Chamber. In addition, the appellant must substantiate that the decision under review would have been substantially different, had it not been for the error. ${ }^{62}$ [Footnotes omitted.]

65. In alleging factual errors, the appellant must "set out in particular why the Trial Chamber's findings were unreasonable. In that respect, repetitions of submissions made before the Trial Chamber as to how the evidence should be assessed are insufficient if such submissions merely put forward a different interpretation of the evidence". 63

66. However, assessing whether or not the trial chamber applied the standard of proof correctly is the responsibility of the Appeals Chamber. The accused does not have to prove that the trial chamber made a factual error. It suffices for him or her to identify sources of doubt about the accuracy of the trial chamber's findings to oblige the Appeals Chamber to independently review the trial chamber's reasoning on the basis of the evidence that was available to it. If the trial chamber fails to accompany its finding with reasoning of sufficient clarity, which unambiguously demonstrates both the evidentiary basis upon which the finding is based as well as the trial chamber's analysis of it, the Appeals Chamber has no choice but to set aside the affected finding, since the lack of adequate reasoning renders the finding unreviewable, thereby constituting a serious procedural error. It is also important 
that, in all cases before the Court, the duty to substantiate errors in the conviction decision should not lead to a reversal of the burden of proof.

\section{F. Degree of appellate deference to be accorded to the factual findings of the Trial Chamber in the present case}

67. The degree of appellate deference was raised in Mr Bemba's Appeal Brief and, subsequent to the Appeal's Chamber's question - "What level of deference should the Appeals Chamber accord to the Trial Chamber's factual findings" - also discussed during the hearing in January $2018 .{ }^{64}$

68. Mr Bemba's argument is that the absence of thorough reasoning in the Conviction Decision, upon which deference depends, and certain alleged flaws in the manner in which the Trial Chamber appreciated the evidence, treated witnesses or approached procedure, are so egregious as to displace the customary standard of deference and entail the application of a much higher level of appellate scrutiny to the factual findings in the instant case. ${ }^{65}$ The Appeals Chamber sees no reason as to why the appellate standard for factual errors set out above, which is designed to identify an unreasonable assessment of the facts of the case, including in the appraisal of evidence and in the espousal of rationale, would be insufficient to attend to such alleged deficiencies in a trial judgment.

69. To the extent that it is argued that the judicial decision-making process of the triers of fact was unfair and did not allow for effective intervention of the parties or that specific allegations about improper procedure, flawed evidential assessments, lack of reasoning and bias are made, they will in any case be encompassed within the Appeals Chamber's examination of what was reasonable for the Trial Chamber to have established beyond reasonable doubt in the circumstances of the specific case and, if established, discernible from that enquiry.

70. The Appeals Chamber thus finds it unnecessary to modify the standard of review, as set out above, for its assessment of the Trial Chamber's factual findings.

\section{MERITS}

\section{A. Preliminary issues: Additional Evidence Application and Prosecutor's Request to File an Additional Authority}

71. Before addressing the second ground of appeal and part of the third ground of appeal, the Appeals Chamber shall dispose of two outstanding procedural applications: Mr Bemba's Additional Evidence Application and the Prosecutor's Request to File an Additional Authority.

72. On 19 September 2016, Mr Bemba filed the Additional Evidence Application, requesting the admission of 23 documents into evidence on appeal. ${ }^{66}$ As Mr Bemba submits that these documents relate to the first ground of appeal, ${ }^{67}$ which will not be addressed in this judgment, the majority of the Appeals Chamber considers it unnecessary to address the merits of the Additional Evidence Application. Accordingly, Mr Bemba's Additional Evidence Application is dismissed.

73. On 13 April 2018, the Prosecutor sought leave to file details of a paper on superior responsibility under article 28 published online in April 2018 in a "respected academic journal". ${ }^{68} \mathrm{Mr}$ Bemba responded to this request on 20 April 2018, submitting that it should be dismissed. ${ }^{69}$ The Appeals Chamber considers that it has sufficient information for the purposes of determining the issues arising in the present appeal and that it is unnecessary for it to receive details of the paper proposed by the Prosecutor. Accordingly, the Prosecutor's Request to File an Additional Authority is rejected.

\section{B. Second ground of appeal: "The conviction exceeded the charges"}

74. Mr Bemba alleges that "[n]early two thirds of the underlying acts for which [he] was convicted were not included or improperly included in the Amended DCC and fall outside the scope of the charges". ${ }^{70} \mathrm{He}$ asserts that the Trial Chamber erred in law in relying on these acts for the conviction. ${ }^{71} \mathrm{Mr}$ Bemba also contends that the Trial Chamber should not have relied on "incidents" or "underlying acts" described by victims V1 and V2 to convict him, as their statements were provided after the start of the trial. ${ }^{72}$ The Appeals Chamber notes that 
Mr Bemba, the Prosecutor as well as the Trial Chamber use the term "underlying acts". It refers to specific criminal acts, such as the murder or rape of a particular victim. The Appeals Chamber shall refer to these acts in what follows as "criminal acts", which it considers to be a more descriptive term.

\section{Relevant procedural background}

75. During the confirmation process, in the Amended Document Containing the Charges, the Prosecutor listed a number of alleged criminal acts of murder, rape and pillaging, but, through the use of expressions such as "include" or "include but are not limited to", indicated that this list was not complete or exhaustive. ${ }^{73}$

76. The Pre-Trial Chamber confirmed in broad terms charges of murder as a war crime and as a crime against humanity, ${ }^{74}$ rape as a war crime and as a crime against humanity, ${ }^{75}$ and pillaging as a war crime, ${ }^{76}$ finding substantial grounds to believe that these crimes had been perpetrated against civilians by MLC soldiers in the CAR from on or about 26 October 2002 to 15 March 2003. The Pre-Trial Chamber did not enter findings that there were substantial grounds to believe that specific acts of murder, rape and pillaging had been committed, but rather "relied on" or "dr[ew] attention, in particular" to certain events and evidence to support its overall conclusions. ${ }^{77}$

77. Following the confirmation of charges, the Trial Chamber requested the Prosecutor to provide a second amended document containing the charges, ${ }^{78}$ which was submitted on 4 November $2009 .{ }^{79} \mathrm{Mr}$ Bemba challenged the Second Amended Document Containing the Charges on 12 February 2010, complaining inter alia that the Prosecutor had reinterpreted the conclusions of the Pre-Trial Chamber by adding new allegations that were not confirmed, reformulating the Pre-Trial Chamber's conclusions and adding words and expressions such as "on or about" or "including but not limited to" with the aim of broadening the charges. ${ }^{80}$

78. In its Decision on Mr Bemba's Challenge to the Second Amended Document Containing the Charges, the Trial Chamber considered that "the Confirmation Decision is the authoritative document for all trial proceedings". 81 It found that the charging document "must describe the charges by reference to the 'statement of facts' underlying the charges confirmed by the Pre-Trial Chamber - its precise factual findings". ${ }^{82}$ With respect to Mr Bemba's proposal to limit the charge of pillaging to those locations that were specifically listed by removing the word "include", the Trial Chamber noted that the Pre-Trial Chamber had not intended to limit acts of pillaging to the four locations cited in the Second Amended Document Containing the Charges. ${ }^{83}$ It thereby allowed for the subsequent addition of new locations where pillaging had allegedly taken place. The Trial Chamber also permitted the inclusion of allegations on which the Pre-Trial Chamber had not made any express findings if the allegations "merely describe[d] the facts and circumstances upon which the charges have been confirmed" or "d[id] not exceed the scope of the charges". ${ }^{84}$ A corrected revised version of the Second Amended Document Containing the Charges ${ }^{85}$ was filed on 14 October 2010 and the trial proceeded on that basis.

79. On 4 November 2009 and 15 January 2010, the Prosecutor filed the Prosecutor's Summary Presentation of Evidence and the Prosecutor's Updated Summary Presentation of Evidence, respectively, in which information on further individual acts was provided. On 6 November 2009, the Prosecutor indicated her intention to rely on a few more criminal acts, when disclosing evidence. ${ }^{86}$

80. In the Conviction Decision, the Trial Chamber reiterated that the Confirmation Decision "defines the scope of the charges". ${ }^{87}$ It found:

The provision of additional information by the Prosecution relating to the charges should not exceed the scope of, and thereby result in any amendment to, the facts and circumstances described in the charges as confirmed. In determining whether various facts exceeded that scope, the Chamber adopted the following approach:

a. When the Pre-Trial Chamber excluded any facts, circumstances, or their legal characterisation, the Chamber found that they exceeded the scope of the confirmed charges; and

b. In relation to factual, evidential details, when the Pre-Trial Chamber excluded or did not pronounce upon them, the Chamber did not rule out the possibility that, at trial, the information 
could qualify as evidential detail supporting the facts and circumstances described in the charges. ${ }^{88}$ [Footnotes omitted]

81. Regarding the Confirmation Decision in the present case, the Trial Chamber noted that:

[T] he Pre-Trial Chamber "in particular, [drew] attention to" certain events and evidence, but did not limit the charges to those particular events or that particular evidence. Rather, the Pre-Trial Chamber broadly defined the temporal and geographical scope of the alleged attack on the civilian population and the alleged armed conflict on CAR territory from on or about 26 October 2002 to 15 March 2003. In Decision 836, the Chamber affirmed that the charges as drafted in the Second Amended DCC conformed to the Confirmation Decision, insofar as they used inclusive language, for example, the phrases "include" and "include, but are not limited to". Further, the Chamber affirmed that the confirmed charges included acts of murder, rape, and pillaging committed on CAR territory, including in Bangui, PK12, Mongoumba, Bossangoa, Damara, Sibut, and PK22, from on or about 26 October 2002 to 15 March 2003. ${ }^{89}$ [Footnotes omitted]

82. Having thus defined the scope of the confirmed charges, the Trial Chamber noted that it must "assess whether the Accused received adequate notice" thereof, taking into account "all documents designed to provide information about the charges, including the Confirmation Decision and "auxiliary documents". 90 It further noted that, in cases where the accused was geographically remote from the scene of the crimes, "it may not be possible to plead evidential details concerning the identity or number of victims, precise dates, or specific locations" and that, "in cases of mass crimes, it may also be impracticable to provide a high degree of specificity in relation to those matters". ${ }^{91}$

83. Following these principles, the Trial Chamber determined that Mr Bemba had been provided with "adequate notice" regarding criminal acts that were: (i) "relied on" by the Pre-Trial Chamber for the purposes of the confirmation of charges; ${ }^{92}$ (ii) included in the Second Amended Document Containing the Charges, filed before the evidentiary hearings commenced, although the Pre-Trial Chamber had declined to rely on these criminal acts for the purposes of the Confirmation Decision; ${ }^{93}$ (iii) included in the Prosecutor's Summary Presentation of Evidence and the Prosecutor's Updated Summary Presentation of Evidence, filed before the evidentiary hearings commenced, ${ }^{94}$ (iv) relied on in the Prosecutor's Closing Brief and "upon which [she] originally indicated her intention to rely on 6 November 2009" in the disclosure process and in the Prosecutor's Updated In-Depth Analysis Chart of Incriminatory Evidence filed before the evidentiary hearings commenced. ${ }^{95}$ As all of these criminal acts "were allegedly committed in the CAR between 26 October 2002 and 15 March 2003", it further found "that they fall within the scope of the charges". 96

84. In addition, the Trial Chamber noted that the witness statements of V1 and V2 detailing alleged acts of murder, rape and pillaging had been provided to the parties on 1 February 2012, after the evidentiary hearings had commenced. ${ }^{97}$ The Trial Chamber noted that Mr Bemba had not challenged the proposed testimony on the basis that the acts described exceeded the scope of the charges, but only because the "evidence was 'cumulative' of the prosecution evidence of "crimes relevant to the DCC". 98 It found that it could "rely on the[se] [criminal] acts $[\ldots]$ as they provide evidential detail as to the facts set out in the charges". 99

\section{Submissions of the parties and participants}

85. Mr Bemba submits that he was convicted of criminal acts that fall outside the scope of the charges. He advances three arguments in support of this submission: (i) the conviction was partly based on unconfirmed criminal acts; ${ }^{100}$ (ii) V1 and V2's evidence cannot form the basis of a conviction; ${ }^{101}$ and (iii) the conviction was partly based on criminal acts improperly included in the Corrected Revised Second Amended Document Containing the Charges. $^{102}$

86. In relation to the first argument, Mr Bemba submits that "the decision on the confirmation of the charges defines the parameters of the charges at trial" and criminal acts "form an integral part of the charges" ${ }^{103}$ He contends that, "[i]f [a criminal] act was not confirmed by the Pre-Trial Chamber, absent a successful [...] application [to amend the charges], it does not form part of the charges and cannot be used to found a conviction". ${ }^{104}$ 
He acknowledges that in certain circumstances, auxiliary documents may contain further details about the charges confirmed, but submits that "[f]urther details" are necessarily those which elaborate or clarify the existing charges such as, for example, the identity of a previously unidentified victim, or corroborative evidence as to the identity of the perpetrator". ${ }^{105} \mathrm{He}$ contends that to allow a "Trial Chamber to add new [criminal] acts, which are themselves individual crimes, capable of amounting to charges, as "further details' would be to amend the charges" without following the procedure envisaged under the Statute. ${ }^{106} \mathrm{He}$ further argues that adding criminal acts through auxiliary documents "would render redundant a central part of the confirmation process, namely the Pre-Trial Chamber's analysis of individual incidents" and "would also allow the Prosecution to seek to rehabilitate acts, expressly rejected by the Pre-Trial Chamber, via additional disclosure in auxiliary documents". ${ }^{107}$ Finally, Mr Bemba contends that, "[g]iven the 'strong link' between notice of the charges and the right of an accused to prepare his defence, the fairness of the proceedings is also jeopardised". 108

87. In relation to the second argument and without prejudice to the first, Mr Bemba contends that the Trial Chamber should not have relied on "incidents" or criminal acts described by V1 and V2 to convict him. ${ }^{109}$ He highlights that V1's and V2's statements were provided on 1 February 2012, after the start of the trial, and describe additional [criminal] acts and not just " "evidential detail as to the facts set out in the charges". 110

88. With regard to the third argument, Mr Bemba argues that the Trial Chamber erred in convicting him on the basis of two criminal acts upon which the Pre-Trial Chamber declined to rely in confirming the charges: the rape of unidentified victims 1 to 35 and the pillaging of the belongings of P68 and her sister-in-law. ${ }^{111}$ Regarding the rape of unidentified victims 1 to 35, he submits that the Pre-Trial Chamber attached low probative value to P47's evidence and did not confirm this incident. ${ }^{112}$

Regarding the pillaging of the belongings of P68 and her sister-in-law, he argues that the Pre-Trial Chamber "only took note of the corroborative value of [P68's] statement in relation to "accounts of large-scale pillaging"". ${ }^{113} \mathrm{He}$ contends that the Pre-Trial Chamber's reference "was not intended to support the inclusion of [a criminal] act in the charges" and that this "is underlined by its recognition of the generality of the witness' evidence". ${ }^{114} \mathrm{He}$ argues that the pillaging of the belongings of P68's sister-in-law was not included in the Amended Document Containing the Charges, but appeared for the first time in auxiliary documents. ${ }^{115} \mathrm{He}$ submits that, as this criminal act was not confirmed, it falls outside the scope of the charges. ${ }^{116}$

89. Mr Bemba argues that "the incidents are 'facts' which 'support the [contextual] legal elements of the crime charged". ${ }^{117}$ In response to the question of whether a broadly described crime or an individual act are "facts" within the meaning of article 74 (2) of the Statute, Mr Bemba submits that they both are. ${ }^{118}$ Relying on the Chambers Practice Manual, he argues that "no threshold of specificity of the charges can be established in abstracto" and that it "depends on the nature of the case". 119

90. Referring to regulation 52 (b) of the Regulations of the Court and rule 121 (3) of the Rules, Mr Bemba argues that the allegation of rape by MLC soldiers in the CAR between on or about 26 October 2002 and 15 March 2003 would not be sufficiently specific and that "[w]ithout the inclusion of any other factual details, it would be a rape charge with [a] 141-day time frame covering a geographic area of approximately 623,000 square [kilometers]". ${ }^{120}$ Mr Bemba submits that wording permitting the Prosecutor to expand the factual parameters of the trial after confirmation should not be allowed. ${ }^{121} \mathrm{He}$ argues that in order to form part of the confirmed charges, criminal acts must be exhaustively listed in the document containing the charges. ${ }^{122} \mathrm{Mr}$ Bemba clarifies that although it is not his position that "the Pre-Trial Chamber must determine whether there is sufficient evidence to support to the requisite standard each [criminal] act included in the DCC and enter a finding on each such act in the confirmation decision", "[i]deally" the Pre-Trial Chamber should do so. ${ }^{123} \mathrm{Mr}$ Bemba submits that the "Trial Chamber has no power to amend the factual allegations comprising the charges confirmed by the Pre-Trial Chamber". ${ }^{124} \mathrm{He}$ contends that criminal acts are facts indispensable for entering a conviction and "must be proved beyond reasonable doubt". ${ }^{125}$

91. The Prosecutor contends that Mr Bemba's conviction did not exceed the charges. ${ }^{126}$ She submits that the PreTrial Chamber and the Trial Chamber clarified that "the scope of the charges was not limited to the individual incidents of killings, rapes and pillaging discussed in the Confirmation Decision, but extended to all such acts committed by MLC soldiers against CAR civilians on CAR territory from on or about 26 October 2002 to 15 March 2003, as 
long as [Mr] Bemba received adequate notice of their details". ${ }^{127}$ The Prosecutor argues that the details of the charges were "broadly set out" in the confirmed charges, but that additional notice was provided in, inter alia, auxiliary documents, including the Corrected Revised Second Amended Document Containing the Charges, the Prosecutor's Updated Summary Presentation of Evidence and the Second Updated In-Depth Analysis Chart of Incriminatory Evidence. ${ }^{128}$ She submits that Mr Bemba did not incur unfair prejudice on account of the manner in which notice was given, as he was able to prepare his defence. ${ }^{129}$ The Prosecutor argues that the sufficiency of notice is not impacted by some victims not being identified by name and some dates differing by a few days. ${ }^{130}$

92. With respect to the allegedly unconfirmed criminal acts, the Prosecutor submits that the "Pre-Trial Chamber acknowledged that the Confirmation Decision need not expressly set out all [criminal acts] of murder, rape and pillaging" and that "expressions such as "[including] but [...] not limited to"" are permissible. ${ }^{131}$ She argues that specific criminal acts are not excluded from the scope of the charges because she had not provided evidence on all criminal acts at the confirmation stage or because the Pre-Trial Chamber had not relied on certain evidence before it. ${ }^{132}$ The Prosecutor submits that she was required to provide details of the charges "to the greatest degree of specificity possible" and that "the Pre-Trial Chamber did not need to set out every underlying act in the Confirmation Decision". ${ }^{133}$ She contends that she was entitled to provide further details in auxiliary documents, "including dates and locations of certain acts, and victims' identities" ${ }^{134}$ Regarding the criminal acts to which V1 and V2 referred in their testimony, the Prosecutor submits that they fell within the scope of the confirmed charges and that, because Mr Bemba was notified of these incidents after the trial had commenced, "any potential prejudice" was "effectively cured". ${ }^{135}$ She contends that the late notice did not affect Mr Bemba's rights and that at trial he never claimed that the proposed evidence of V1 and V2 would affect his rights. ${ }^{136}$ As regards the criminal acts which the Pre-Trial Chamber allegedly declined to confirm, the Prosecutor submits that that Chamber simply did not rely on the evidence of P47 and P68 to confirm the charges of rape and pillaging, respectively, which does not mean that these criminal acts were not confirmed. ${ }^{137}$ The Prosecutor contends that Mr Bemba received timely notification of the details of these charges. ${ }^{138}$

93. The Prosecutor clarifies that Mr "Bemba was charged with, and convicted of crimes of murder, rape and pillaging committed by MLC soldiers on the territory of the CAR from 26 October 2002 to 15 March 2003" and that such are "the facts and circumstances" in the present case. ${ }^{139}$ The Prosecutor submits that the specific acts underlying these crimes are not material facts, but subsidiary facts or evidence, "used in this case to establish the material fact". ${ }^{140}$ The Prosecutor argues that the Trial Chamber's "convictions were limited to evidence regarding these specific acts of murder, rape and pillaging" $" 141$ or to those acts of which sufficient notice had been given. ${ }^{142}$ The Prosecutor submits that since the "individual acts of murder, rape and pillaging were subsidiary facts or evidence[,] [...] the Trial Chamber did not need to enter findings beyond reasonable doubt in relation to each of them". ${ }^{143}$

94. The Prosecutor argues that since Mr Bemba was remote from the crimes and he was charged under article 28 of the Statute with "a large pattern of crimes committed by his subordinates in a neighbouring country", the Trial Chamber could have convicted Mr Bemba also on the basis of other acts of rape, murder and pillaging, the evidence of which it considered in relation to its finding of a widespread attack against the civilian population. ${ }^{144}$

95. Mr Bemba replies that "[t]he Prosecutor misstates the law in claiming" that the prejudice caused by late notice of charges or criminal acts can be cured. ${ }^{145}$ He claims that material received after the trial has commenced is only "relevant to "whether prejudice caused by lack of detail in the charges may have been cured", but that notice of the charges by V1 and V2 should have been given to him before trial. ${ }^{146}$

96. The Victims submit that the decision on the confirmation of charges only defines "the parameters of the charges" and not the charges themselves, and that, therefore, the charges are not limited to the criminal acts confirmed by the Pre-Trial Chamber. ${ }^{147}$ The Victims contend that the Pre-Trial Chamber defined the scope of the charges broadly and that other criminal acts could be included, "as long as they fell within the scope of the charges and were not excluded by the Pre-Trial Chamber". ${ }^{148}$ The Victims argue that in view of the nature of the crimes and the mode of responsibility, with which Mr Bemba was charged, the Prosecutor "[could not] be expected to prove every crime committed by MLC troops in the CAR during the 2002-2003 operation" ${ }^{149}$ The Victims submit that Mr Bemba was informed of the charges in sufficient detail before the start of the trial. ${ }^{150}$ As regards the testimony of V1 and V2, the Victims argue that they were not authorised to submit evidence at the pre-trial 
stage and, as a result, the acts to which V1 and V2 testified could not be notified to Mr Bemba before the commencement of the trial. ${ }^{151}$ The Victims submit that the notice which Mr Bemba received was "sufficiently prompt and detailed" and that he was given "adequate time to prepare his defence". ${ }^{152}$

97. In reply to the Victims' Observations, Mr Bemba submits that if the reasoning of the Victims were accepted, any evidence that was not authorised or unavailable at the confirmation stage could be relied upon to convict him. ${ }^{153}$ He further argues that the Victims and the Prosecutor "enjoyed close cooperation" and it would have therefore been obvious to the Victims during the pre-confirmation phase of the case that "the Prosecutor had scant evidence of underlying acts of murder". ${ }^{154} \mathrm{Mr}$ Bemba contends that "[he] could not have anticipated that he was being required to defend against, for example, a charge of murder in Mongoumba, which fell outside the scope of the Second Revised Amended DCC". ${ }^{155}$

\section{Determination by the Appeals Chamber}

98. The Appeals Chamber notes that the present ground of appeal concerns the scope of the charges (article 74 (2) of the Statute) and not whether Mr Bemba was informed in detail and sufficiently in advance of the charges on the basis of which he was convicted. Indeed, Mr Bemba does not argue on appeal that he did not receive sufficient notice of the allegations against him, including in respect of the criminal acts in question. Nonetheless, the Prosecutor's arguments in response are, to a large extent, based on the assumption that notice to the accused person is relevant to the determination of whether a criminal act falls within the scope of the charges. ${ }^{156}$ In its discussion of the present ground of appeal, the Appeals Chamber will focus on the scope of the charges.

99. Mr Bemba's central argument is that the Conviction Decision exceeded the "facts and circumstances described in the charges" in violation of article 74 (2) of the Statute because he was convicted partly based on individual acts of murder, rape and pillaging committed against particular victims at specific times and places that had not been confirmed in the Confirmation Decision. In his view, the scope of the trial against him was limited to the criminal acts that were specifically confirmed by the Pre-Trial Chamber in the Confirmation Decision, arguing that "[i]f [a criminal] act was not confirmed by the Pre-Trial Chamber, [...] it does not form part of the charges and cannot be used to found a conviction". ${ }^{157}$

100. The Appeals Chamber will therefore address two main issues, namely, (i) the scope of the Conviction Decision; and (ii) whether the Conviction Decision exceeded the scope of the charges.

\section{(a) Scope of the Conviction Decision}

101. Before assessing Mr Bemba's argument, the Appeals Chamber considers it necessary to clarify what Mr Bemba was convicted of. In the disposition of the Conviction Decision, the Trial Chamber stated that Mr Bemba was:

GUILTY, under Article 28(a) of the Statute, as a person effectively acting as a military commander, of the crimes of: -

(a) Murder as a crime against humanity under Article 7(1)(a) of the Statute;

(b) Murder as a war crime under Article 8(2)(c)(i) of the Statute;

(c) Rape as a crime against humanity under Article 7(1)(g) of the Statute;

(d) Rape as a war crime under Article 8(2)(e)(vi) of the Statute; and

(e) Pillaging as a war crime under Article $8(2)(e)(v)$ of the Statute. ${ }^{158}$

102. This disposition, however, which is formulated in the most general terms, must be understood in the context of the other findings in the Conviction Decision, which further explain what Mr Bemba was convicted of. Notably, in the Conviction Decision, the Trial Chamber found 
beyond reasonable doubt that MLC soldiers committed the war crime of murder and the crime against humanity of murder in the CAR between on or about 26 October 2002 and 15 March 2003. ${ }^{159}$

103. Similar findings were entered in relation to rape as a war crime and crime against humanity and pillage as a war crime. ${ }^{160}$ While these findings provide more detail than the disposition, notably by defining, in broad terms, the time period and area of the crimes, as well as the affiliation of the direct perpetrators, important information is still missing. Notably, there is no reference to even an approximate number of the individual criminal acts of murder, rape and pillage that the Trial Chamber found established, or any further demarcation of the scope of the conviction, which would appear to cover, potentially, all such crimes committed by MLC soldiers in a territory of more than 600,000 square kilometers and over a period of more than four and a half months.

104. Therefore, the Appeals Chamber considers, by majority, Judge Monageng and Judge Hofmański dissenting, that the Conviction Decision must be understood as convicting Mr Bemba of the specific criminal acts of murder, rape and pillage that the Trial Chamber found to be established beyond a reasonable doubt and which were indeed recalled in the concluding sections of the Conviction Decision in relation to each crime. ${ }^{161}$ Thus, in the circumstances of the present case, the broad disposition in the Conviction Decision and the only slightly less broad conclusions of the Trial Chamber in relation to the crimes against humanity and war crimes of murder and rape and the war crime of pillage ${ }^{162}$ do not, in reality, reflect what Mr Bemba was convicted of. Rather, they are summaries of the Trial Chamber's findings in relation to the criminal acts of murder, rape and pillage that had been established beyond reasonable doubt; the conviction of Mr Bemba, however, was entered in relation to these specific criminal acts. The Appeals Chamber therefore rejects, by majority, Judge Monageng and Judge Hofmański dissenting, the Prosecutor's submission, at the appeal hearing, that Mr Bemba was charged with, and convicted of, generally crimes of murder, rape and pillaging committed by MLC soldiers on the territory of the CAR from 26 October 2002 to 15 March 2003, which constituted the "the facts and circumstances" in the present case, ${ }^{163}$ and that the criminal acts were merely "subsidiary facts" or "evidence", "used in this case to establish the material fact". ${ }^{164}$

\section{(b) Whether the Conviction Decision exceeded the scope of the charges}

105. Having thus clarified what Mr Bemba was convicted of, the Appeals Chamber shall now turn to the central question raised by Mr Bemba under this ground of appeal, namely whether his conviction exceeded the charges against him. The controlling provision in this regard is article 74 (2) of the Statute, which provides in relevant part:

The decision [of the Trial Chamber at the end of the trial] shall not exceed the facts and circumstances described in the charges and any amendments to the charges.

106. Thus, to answer the question raised by Mr Bemba, it is necessary to determine which "facts and circumstances" have been described in the charges, and whether they correspond to, or encompass, the criminal acts which Mr Bemba was convicted of.

107. The Appeals Chamber recalls that the Confirmation Decision in its operative part was equally broad as the disposition of the Conviction Decision: the charges against Mr Bemba were "confirmed" in relation to categories of crimes, without any further qualification. ${ }^{165}$ Clearly this broad formulation would have been an insufficient basis to bring Mr Bemba to trial and cannot be said to amount to a description of "facts and circumstances" in terms of article 74 (2) of the Statute.

108. The pre-confirmation Amended Document Containing the Charges, on the other hand, provided more detail in its operative part. For instance, in relation to rape as a crime against humanity, the Amended Document Containing the Charges contained the following formulation:

From on or about 26 October 2002 to 15 March 2003, Jean-Pierre BEMBA committed, jointly with another, Ange-Félix Patassé, crimes against humanity through acts of rape upon civilian men, woman $[\mathrm{sic}]$ and children in the Central African Republic, in violation of Articles $7(1)(\mathrm{g})$ and $25(3)$ (a) or 28(a) or 28(b) of the Rome Statute. 
Civilian men, women and children in the Central African Republic include, but are not limited to REDACTED, 26 or 27 October 2002, Fou; REDACTED, 26 or 27 October 2002, Fou; REDACTED, 26 October 2002, PK 12; REDACTED, 30 October 2002, Boy-Rabé; REDACTED, 8 November 2002, PK 12; REDACTED, 8 November 2002, PK 12; REDACTED, 8 November 2002, PK 12; REDACTED, 8 November 2002, PK 12; REDACTED, on or about 8 November 2002, PK 12; REDACTED, 8 November 2002, PK 12; REDACTED, on or about 5 March 2003, Mongoumba; Unidentified Victims 1 to 8, 26 October and 31 December 2002, Bangui; Unidentified Victims 9 to 30, October 2002 and 31 December 2002, Bangui; Unidentified Victims 31 to 35, October 2002 to 31 December 2002, Bangui. ${ }^{166}$

109. The passages in relation to the other crimes followed the same structure: the first paragraph outlined in very general terms the temporal and geographical frame during which crimes were allegedly committed, while the second paragraph listed individual criminal acts of murder, rape or pillage. ${ }^{167}$ The use of the words "include, but are not limited to" indicated that, according to the Prosecutor, these lists of criminal acts were not exhaustive.

110. The Appeals Chamber considers that the formulation in the operative part of the Confirmation Decision as well as that in the first paragraphs of the passages in relation to each category of crimes in the Amended Document Containing the Charges are too broad to amount to a meaningful "description" of the charges against Mr Bemba in terms of article 74 (2) of the Statute. The Appeals Chamber recalls that regulation 52 (b) of the Regulations of the Court stipulates that documents containing the charges must set out a "[a] statement of the facts, including the time and place of the alleged crimes, which provides a sufficient legal and factual basis to bring the person or persons to trial". Simply listing the categories of crimes with which a person is to be charged or stating, in broad general terms, the temporal and geographical parameters of the charge is not sufficient to comply with the requirements of regulation 52 (b) of the Regulations of the Court and does not allow for a meaningful application of article 74 (2) of the Statute.

111. That said, the Appeals Chamber notes that, in the present case, both the Amended Document Containing the Charges and the Confirmation Decision contained more specific factual allegations as to the crimes for which Mr Bemba was to be tried - namely in the form of the identified criminal acts, which were prominently mentioned in the operative part of the Amended Document Containing the Charges and also taken up as part of the evidential analysis in the Confirmation Decision. ${ }^{168}$ Thus, in the present case, the "facts and circumstances" were described, in relation to the crimes, at the level of individual criminal acts.

112. Turning to Mr Bemba's allegation that he was convicted of criminal acts that were outside the scope of the charges, the Appeals Chamber considers that, in light of what has been said above, it is clear that the criminal acts that were mentioned in the Amended Document Containing the Charges and mentioned with approval in the Confirmation Decision were within the scope of this case - a fact that Mr Bemba does not dispute. This concerns the following criminal acts which Mr Bemba was convicted of:

i. the pillaging of P22's uncle's house by MLC soldiers near PK12;

ii. the rapes of P68 and her sister-in-law by MLC soldiers on 27 October 2002 near Miskine High School in Fouh;

iii. the murder of P87's "brother” by MLC soldiers in Boy-Rabé on 30 October 2002;

iv. the rape of P87 by MLC soldiers in Boy-Rabé on 30 October 2002;

v. the pillaging of P87's house by MLC soldiers in Boy-Rabé on or around 30 October 2002

vi. the rape of P22 by MLC soldiers at her uncle's house in PK12 at the end of October 2002;

vii. the pillaging of P42's house by MLC soldiers in PK12 in November 2002;

viii. the rape of P23, his wife (P80), his daughter (P81), and at least one other of his daughters by MLC soldiers at P23's compound in PK12 on 8 November 2002; 
ix. the pillaging of P23's compound (including the belongings of P80 and P81) by MLC soldiers in PK12 on 8 November 2002;

x. the rape of P42's daughter by MLC soldiers at the end of November 2002 in PK12; and

xi. the rape of P29 by MLC soldiers on 5 March 2003 in Mongoumba. ${ }^{169}$

113. As to the criminal acts that were mentioned in the Amended Document Containing the Charges, but on which the Pre-Trial Chamber decided not to rely to confirm the charges, the Appeals Chamber notes that Mr Bemba argues that their confirmation was rejected by the Pre-Trial Chamber and that they are, therefore, outside the scope of the present case. ${ }^{170}$ This argument disregards, however, that the Pre-Trial Chamber seemingly did not consider that it had to "confirm" all (or indeed any) individual criminal acts. ${ }^{171}$ The Appeals Chamber considers that, at this stage of the proceedings - where an appeal is brought against the final decision of the Trial Chamber-it is immaterial whether the approach of the Pre-Trial Chamber was correct or not. It was clear to all parties and participants, including to Mr Bemba, that the Pre-Trial Chamber did not intend to exclude the criminal acts in question from the case against Mr Bemba. Rather, because of evidential shortcomings it had identified, it decided not to rely on them for the purpose of confirmation. ${ }^{172}$ For that reason, the Appeals Chamber considers that the criminal acts in question form part of the "facts and circumstances described in the charges" and were therefore within the scope of this trial. This concerns the following criminal acts which Mr Bemba was convicted of:

i. the pillaging of the belongings of P68 and her sister-in-law in Bangui at the end of October 2002; and

ii. the rape of eight unidentified victims at the Port Beach naval base in Bangui at the end of October or beginning of November 2002. ${ }^{173}$

114. The Appeals Chamber recalls that, once the charges against Mr Bemba were confirmed and the Trial Chamber was seized of the case against him, the Prosecutor added, by means of disclosure and inclusion in auxiliary documents, criminal acts of murder, rape and pillage. ${ }^{174}$ This appears to have been consistent with the Trial Chamber's understanding that the Pre-Trial Chamber had not meant to limit the criminal acts covered by this case to those mentioned in the Amended Document Containing the Charges.

115. While the Appeals Chamber notes that the Trial Chamber's understanding of the relevance of the specific criminal acts of murder, rape and pillage that were charged corresponded to the Pre-Trial Chamber's approach thereto, the Appeals Chamber nevertheless considers that the criminal acts that the Prosecutor added after the Confirmation Decision was issued cannot be said to have been part of the "facts and circumstances described in the charges" in terms of article 74 (2) of the Statute. This is because, as set out above, in the present case the Prosecutor had formulated the charges at a level of detail sufficient for the purposes of that provision only in respect of the criminal acts. For that reason, adding any additional criminal acts of murder, rape and pillage would have required an amendment to the charges, which, however, did not occur in the case at hand. In this regard, the Appeals Chamber wishes to underline that this is not to say that adding specific criminal acts after confirmation would in all circumstances require an amendment to the charges - this is a question that may be left open for the purposes of disposing of the present ground of appeal; nevertheless, given the way in which the Prosecutor has pleaded the charges in the case at hand, this was the only course of action that would have allowed additional criminal acts to enter the scope of the trial. As that did not occur in the case at hand, the Appeals Chamber finds, by majority, Judge Monageng and Judge Hofmański dissenting, that the criminal acts that were added after the Confirmation Decision had been issued did not form part of the "facts and circumstances described in the charges" - to the extent that the document containing the charges was not amended to reflect them - and Mr Bemba could therefore not be convicted of them. The same applies to the criminal acts put forward by the Victims.

\section{(c) Conclusion}

116. In view of the foregoing considerations, the Appeals Chamber grants this ground of appeal and finds, by majority, Judge Monageng and Judge Hofmański dissenting, that the Trial Chamber erred when it convicted Mr Bemba of the following acts, which did not fall within the "facts and circumstances described in the charges" in terms of article 74 (2) of the Statute: 
i. The murder of P69's sister in PK12 the day after the MLC's arrival in PK12;

ii. Pillaging of the belongings of P69's sister in PK12 the day after the MLC arrived;

iii. Pillaging of the belongings of P69 in PK12 the day after the MLC arrived;

iv. Pillaging of the belongings of P110 in PK12 the day after the MLC arrived;

v. Pillaging of the belongings of P79 and her brother in PK12 several days after the MLC's arrival;

vi. The rape of P79 and her daughter in PK12 several days after the MLC arrived in PK12;

vii. Pillaging of the property of V2 in Sibut in the days after the MLC's arrival.

viii. Pillaging of the belongings of P108 in PK12 during the MLC's presence;

ix. The rape of two unidentified girls aged 12 and 13 years in Bangui on or around 30 October 2002;

x. Pillaging of the belongings of P119 in Bangui after 30 October 2002;

xi. Pillaging of the belongings of P112 in PK12 in November 2002;

xii. The rape of a woman in the bush outside of PK22 in November 2002;

xiii. Pillaging of the belongings of a woman in the bush outside PK22 in November 2002;

xiv. The rape of P69 and his wife in PK12 at the end of November 2002;

xv. Pillaging of the belongings of P73 in PK12 at the end of November 2002;

xvi. The rape of V1 in Mongoumba on 5 March 2003;

xvii. Pillaging of the property of V1, a church, nuns, priests, an unidentified "Muslim" man and his neighbour, the gendarmerie, and mayor in Mongoumba on 5 March 2003; and

xviii. The murder of an unidentified "Muslim" man on 5 March 2003 in Mongoumba witnessed by V1.

117. The Appeals Chamber notes that the Trial Chamber relied on the criminal acts that it found had been established beyond reasonable doubt, including those listed in the preceding paragraph, also for its finding regarding the contextual element of crimes against humanity. In the view of the Appeals Chamber, this did not amount to an error. While the Trial Chamber could not convict Mr Bemba of these criminal acts, they could nevertheless be taken into account for the finding regarding the contextual element of crimes against humanity, which operates at a higher level of abstraction. The Appeals Chamber also notes in this regard that $\mathrm{Mr}$ Bemba has not argued that he has not received sufficient notice of the allegations regarding these criminal acts and there is no unfairness arising from the Trial Chamber having relied on these criminal acts for the purpose of the contextual element of crimes against humanity.

118. Nevertheless, as regards Mr Bemba's conviction, the only criminal acts that the Trial Chamber found to be established beyond reasonable doubt that were within the scope of the charges were thus:

i. The rape of P87 in Bangui on or around 30 October 2002;

ii. Pillaging of the property of P87 and her family in Bangui on or around 30 October 2002;

iii. The murder of P87's "brother" in Bangui at the end of October 2002;

iv. The rape of P68 and P68's sister-in-law in Bangui at the end of October 2002;

v. The rape of P23, P80, P81, P82, and two of P23's other daughters in PK12 in early November 2002;

vi. Pillaging of the property of P23, P80, P81, and P82 in Bangui in early November 2002;

vii. The rape of P22 in PK12 on or around 6 or 7 November 2002;

viii. Pillaging of the property of P22 and her uncle in PK12 on or around 6 or 7 November 2002; 
ix. The rape of P42's daughter in PK12 around the end of November 2002;

x. Pillaging of the property of P42 and his family in PK12 at the end of November 2002; and

xi. The rape of P29 in Mongoumba on 5 March 2003.

119. This means that Mr Bemba was convicted of one murder, the rape of 20 persons and five acts of pillaging.

\section{Third ground of appeal: Command Responsibility: Mr Bemba took all necessary and reasonable measures}

120. For the reasons set out above, ${ }^{175}$ the Appeals Chamber shall only address in this section Mr Bemba's argument that the Trial Chamber erred when it found that he was responsible as a commander pursuant to article 28 (a) of the Statute for crimes that MLC troops had committed during the 2002-2003 CAR Operation.

\section{Relevant Part of the Impugned Decision}

121. The Trial Chamber found that what constitutes "all necessary and reasonable measures" is to be established on a "case-by-case basis", focusing on the "material power" of the commander. ${ }^{176}$

122. The Trial Chamber found that Mr Bemba took "a few measures" in response to allegations of crimes committed by MLC troops in the CAR which included the following. ${ }^{177}$ First, the Mondonga Inquiry, ${ }^{178}$ established in the "initial days of the 2002-2003 CAR Operation", which led to Colonel Mondonga, on 27 November 2002, forwarding the case file containing information on the proceedings against Lieutenant Willy Bomengo and other soldiers of the 28th Battalion arrested in Bangui on 30 October 2002 on charges of pillaging ("Bomengo case file"), ${ }^{179}$ to the MLC Chief of Staff, copying Mr Bemba ${ }^{180}$ Second, the visit to the CAR "on or around 2 November 2002", during which Mr Bemba met with the UN representative in the CAR (General Cissé) and President Patassé. ${ }^{181}$ Third, a speech Mr Bemba gave at PK12 "sometime" in November 2002. ${ }^{182}$ Fourth, the trial of Lieutenant Bomengo and others at the Gbadolite court-martial which commenced on 5 December 2002 with the report of conviction transmitted to Mr Bemba on 12 December 2002. ${ }^{183}$ Fifth, the Zongo Commission which, between 25 and 28 December 2002, questioned witnesses in Zongo, with the head of the commission sending a report on 17 January 2003 to the MLC Secretary General, copied to Mr Bemba. ${ }^{184}$ Sixth, a letter written by Mr Bemba to General Cissé dated 4 January 2003. ${ }^{185}$ Seventh, correspondence in response to the FIDH Report, namely Mr Bemba's letter to the President of the FIDH of 20 February 2003 and the latter's reply on 26 February $2003 .{ }^{186}$ Eighth, the establishment of the Sibut Mission at the "end of February" 2003. ${ }^{187}$

123. The Trial Chamber concluded that these measures were all "limited in mandate, execution, and/or results". ${ }^{188}$ The Trial Chamber made the observations detailed below.

124. The Trial Chamber noted that in a letter dated 27 January 2003, General Cissé responded to Mr Bemba, copying President Patassé, stating that he would bring the contents of Mr Bemba's letter of 4 January $2003{ }^{189}$ to the attention of the UN Secretary-General, offering to participate in any initiative relating to an investigation, and recalling that the CAR and Chad had agreed to create a commission of inquiry. ${ }^{190}$

125. The Trial Chamber found that, "[o]n 13 February 2003, the FIDH issued a report on its investigative mission in Bangui between 25 November and 1 December 2002 entitled Crimes de guerre en République Centrafricaine 'Quand les éléphants se battent, c'est l'herbe qui souffre', [...] based on interviews with various individuals, including CAR authorities, representatives of international organizations and NGOs, medical personnel, and numerous victims". ${ }^{191}$

126. The Trial Chamber noted that on 17 February 2003, Le Citoyen newspaper reported that in the context of the FIDH allegations, Mr Bemba had referred "to the fact that he had arrested eight soldiers for crimes committed in the CAR and that 'he expected an investigation to be initiated between Chad and the CAR'". ${ }^{192}$

127. The Trial Chamber found that Mr Bemba wrote a letter, dated 20 February 2003, to the FIDH President, $\mathrm{Mr}$ Sidiki Kaba, in which he: (i) referred to a previous telephone conversation; (ii) stated that he had ordered the 
establishment of a commission of inquiry charged with verifying allegations, identifying those implicated, and had put them at the disposal of the MLC's military justice system; (iii) referred to his correspondence with General Cissé and the MLC's intention to work with an international commission of inquiry; (iv) complained that the FIDH had not contacted the MLC in order to obtain information; and (v) offered to work with the FIDH. ${ }^{193}$ The Trial Chamber found that in his letter of response, dated 26 February 2003, the President of the FIDH, Mr Kaba, noted that the MLC had prosecuted some individuals accused of pillaging but "expressed serious reservations as to the legitimacy, impartiality, and independence of those proceedings"; informed Mr Bemba that, in light of its mandate, the FIDH had formally seized this Court with the matter on 13 February 2003; and "encouraged Mr Bemba to transmit the information at his disposal to the ICC". ${ }^{194}$

128. The Trial Chamber found that the Mondonga Inquiry did not address the responsibility of commanders, did not question suspects about murder, did not pursue reports of rape, gave special treatment to Colonel Moustapha's battalion, contained irregularities such as questioning witnesses in the middle of the night, and resulted in only seven soldiers ever being arrested and tried, and only in relation to pillaging minor items and small sums of money. ${ }^{195}$

129. With respect to the Zongo Commission established following the trial of Lieutenant Bomengo, the Trial Chamber found that it was geographically limited to Zongo, only involved allegations of pillaging, all its members were MLC officials, it used a limited definition of pillaging, and appeared not to have interviewed any soldiers, despite the ability to do so. ${ }^{196}$

130. Finally, the Trial Chamber was critical of the Sibut Mission, noting that " $[t]$ he reporters only spoke to a narrow selection of interviewees, a number of whom exercised public functions and were linked to President Patassé's regime. The interviews were conducted in a coercive atmosphere with armed MLC soldiers moving among the interviewees and nearby population." 197

131. The Trial Chamber, having found that the measures taken by $\mathrm{Mr}$ Bemba were inadequate in the circumstances, noted that their inadequacy was "aggravated" by indications that they were not "genuine". ${ }^{198}$ The Trial Chamber noted "corroborated evidence" that the "measures were primarily motivated by Mr Bemba's desire to counter public allegations and rehabilitate the public image of the MLC". ${ }^{199}$ It found that the "minimal and inadequate measures", when taken with evidence as to his motives for ordering such measures, "illustrate[d] that a key intention behind the measures Mr Bemba took was to protect the image of the MLC", concluding that "[h]is primary intention was not to genuinely take all necessary and reasonable measures within his material ability to prevent or repress the commission of crimes, as was his duty". 200

132. In relation to the motives behind specific measures taken, the Trial Chamber noted that the Mondonga Inquiry was "allegedly" established to: (i) counter media allegations by showing that only minor items had been looted from the CAR; (ii) demonstrate that action was taken to address allegations of crimes; (iii) vindicate the MLC leadership of responsibility for alleged acts of violence; and (iv) generally rehabilitate the MLC's image. ${ }^{201}$ It noted further that the letter that Mr Bemba sent to General Cissé, the UN Representative in the CAR, was, according to witness testimony, intended to "demonstrate good faith and maintain the image of the MLC, particularly, against a backdrop of negotiations in the DRC as to, inter alia, the role of the MLC in the transitional institutions". ${ }^{202}$ With respect to the withdrawal from the CAR, the Trial Chamber noted that this action was motivated, inter alia, by "pressure from the international community", "directly related to the negotiation of the Sun City agreements". ${ }^{203}$

133. The Trial Chamber noted that "[i]n addition to or instead of the insufficient measures" that Mr Bemba took and "in light of his extensive material ability to prevent and repress the crimes, he "could have, inter alia" taken the following measures:

(i) ensured that the MLC troops in the CAR were properly trained in the rules of international humanitarian law, and adequately supervised during the 2002-2003 CAR Operation; (ii) initiated genuine and full investigations into the commission of crimes, and properly tried and punished any soldiers alleged of having committed crimes; (iii) issued further and clear orders to the commanders of the troops in the CAR to prevent the commission of crimes; (iv) altered the deployment of troops, for example, to minimise contact with civilian populations; (v) removed, replaced, or dismissed officers and soldiers found to have committed or condoned any crimes in the CAR; and/or 
(vi) shared relevant information with the CAR authorities or others and supported them in any efforts to investigate criminal allegations. ${ }^{204}$

134. The Trial Chamber further emphasised that whilst "one key measure at Mr Bemba's disposal was withdrawal of the MLC troops from the CAR", that measure was executed for political reasons and only in March 2003 whereas it found that Mr Bemba had first contemplated withdrawing in November 2002. ${ }^{205}$

135. The Trial Chamber noted Mr Bemba's argument that the Prosecutor's assertions "that [he] could have conducted investigations must be viewed against the difficulties encountered by the CAR authorities in subsequent investigations when General Bozizé took power". ${ }^{206}$ However, it deemed the "difficulties faced by members of the CAR national justice system in conducting a criminal investigation in the CAR shortly after an armed conflict" to be irrelevant. ${ }^{207}$ Furthermore, the Trial Chamber deemed Mr Bemba's "purported comparison" between the Prosecutor's difficulties in conducting investigations in 2006 compared to Mr Bemba's abilities at the time of the 2002-2003 CAR Operation to be unpersuasive, emphasising that Mr Bemba "could and did create commissions and missions in reaction to allegations of crimes, two of which operated on CAR territory at the height of the 2002-2003 CAR Operation". ${ }^{208}$

136. The Trial Chamber ultimately found that Mr Bemba failed to take "all necessary and reasonable measures within his power to prevent or repress the commission of crimes by his subordinates during the 2002-2003 CAR Operation, or to submit the matter to the competent authorities."209 The Appeals Chamber notes that the Trial Chamber did not link Mr Bemba's putative failure to take adequate measures to any of the specific criminal acts - listed above at paragraph 118 - which he was ultimately convicted of.

\section{Submissions of the parties and participants}

137. Mr Bemba asserts that the Trial Chamber erred in finding that he failed to take all measures that were necessary and reasonable to prevent or repress the crimes committed by MLC forces, or to submit the matter to the competent authorities. Mr Bemba makes five submissions: (i) that the Trial Chamber failed to apply the correct legal standard; (ii) that it misappreciated the limitations of the MLC's jurisdiction and competence to investigate; (iii) that it ignored that Mr Bemba had asked the CAR Prime Minister to investigate the allegations; (iv) that it erred by taking into account irrelevant considerations; and (v) that the Trial Chamber's findings on the measures taken were unreasonable, misstated the evidence and ignored relevant evidence. Each submission and the Prosecutor's response thereto will be summarised in turn.

\section{(a) The Trial Chamber failed to assess Mr Bemba's conduct against the correct legal standard}

138. Mr Bemba argues that the Trial Chamber failed to address his conduct against the correct legal standard. First, Mr Bemba submits that a commander need only take such measures that are "within his material possibility". ${ }^{210} \mathrm{Mr}$ Bemba argues that the Trial Chamber failed to consider the "limitations arising from the unique conditions of [the] case" or assess what measures were feasible judged against his "objectively exceptional circumstances". ${ }^{211}$ Mr Bemba asserts that the Trial Chamber erroneously compared his conduct to "a list of hypothetical measures" compiled with the "benefit of hindsight from its post hoc position of superior information rather than that which was available to [him] at the time". ${ }^{212}$ He contends that he is not required to take "every possible measure" conceived in hindsight by jurists, and that it is not the Trial Chamber's role to speculate as to what measures might have "stemmed or mitigated the commission of the crimes"; he argues that its focus should have been on what was feasible and practicable at that time. ${ }^{213} \mathrm{Mr}$ Bemba further notes that the vast majority of international command cases that entailed a finding of guilt, arose where the commander in question either took no measures or was participating or present when the crimes were committed. ${ }^{214}$

139. Second, Mr Bemba submits that in compiling a list of theoretical measures, the Trial Chamber deprived him of the opportunity to present evidence as to why these measures were "not practicable, appropriate, possible (or even legal) in the circumstances". ${ }^{215}$ He states that an accused must be given notice of the measures which the Trial Chamber found he could have taken as a commander and that it would be unfair to convict him without giving 
him the opportunity to defend himself, ${ }^{216}$ given that the jurisprudence does not provide a checklist of specific measures that a commander can take to shield himself from criminal liability. ${ }^{217}$

140. Mr Bemba cites, as examples, the Trial Chamber's reliance on his failure to share relevant information with the CAR authorities ${ }^{218}$ and his failure to alter troop deployment to minimise contact with the civilian population, to demonstrate that, had he known of the "allegation that his duty to take necessary and reasonable measures encompassed altering the deployment of troops", he could have led evidence to show that such measures were "impossible" in the circumstances. ${ }^{219} \mathrm{Mr}$ Bemba argues that he was thus unable to challenge the Trial Chamber's finding that "he could have unilaterally redesigned the deployment of the MLC troops who were acting as part of a larger contingent", without putting lives at risk from "friendly fire". ${ }^{220} \mathrm{He}$ adds that the Prosecutor also accepts that he was entitled to notice, as she listed the measures that she alleged he could have taken in the document containing the charges and, in the Response to the Appeal Brief, argues that he received sufficient notice of those measures, ${ }^{221}$ thereby "rightly acknowledging that Mr Bemba needed notice of them in order to be able to properly prepare his defence $[\ldots]$ and confront these allegations". 222

141. The Prosecutor maintains that Mr Bemba was "required to take all necessary and reasonable measures within his power to prevent or repress MLC crimes or to refer the matter to the competent authorities for investigation and prosecution". ${ }^{223}$ The Prosecutor argues that the Trial Chamber did not err in assessing the measures which $\mathrm{Mr}$ Bemba could take in the CAR. ${ }^{224}$ She argues that, even if the Trial Chamber had erred regarding some measures, this would not materially affect the Conviction Decision. ${ }^{225}$ Moreover, in the view of the Prosecutor, there is no support for the claim that necessary and reasonable measures are separately subject to feasibility requirements (in the sense of not being detrimental to military advantage), provided they are necessary and reasonable. ${ }^{226}$

142. The Prosecutor further submits that "an accused need not be notified in the charges of the specific measures that the Trial Chamber finds he could have taken". ${ }^{227}$ She asserts that, instead, an accused has to be notified of "the conduct by which he may be found to have failed to take the necessary and reasonable measures to prevent such crimes or punish his subordinates. [...] So what must be pleaded are the superior's culpable omissions, or [...] his insufficient actions". ${ }^{228}$ She argues that the ad hoc tribunals have not required that the charges list each potential measure and have generally been satisfied with the charges pleading that the accused did not take the necessary and reasonable measures to prevent or punish criminal acts of subordinates. ${ }^{229}$ Accepting Mr Bemba's proposition that certain measures may be required in one case but not in another, the Prosecutor argues that from the impugned list of measures set out by the Trial Chamber in this case, four are inherent in the duties of a commander and would apply in every case (namely: (i) ensuring proper international humanitarian law training and adequate supervision; (ii) conducting investigations and prosecutions and punishments as necessary; (iii) issuing proper orders; and (iv) replacing, dismissing and removing subordinates). ${ }^{230}$ Whilst conceding that the failure to share information with the CAR authorities or other authorities might be regarded as specific to this case, the Prosecutor argues that it could be regarded as a "subset" of a commander's more general duty to take measures to submit a matter to a competent authority. ${ }^{231}$

143. The Prosecutor maintains that, in any event, Mr Bemba received "sufficient notice" of the measures from the Confirmation Decision and auxiliary documents, citing the Corrected Revised Second Amended Document Containing the Charges, the Prosecutor's Updated Summary Presentation of Evidence and the In-Depth Analysis Chart of Incriminatory Evidence; and argues that while these documents may have used wording different to the Conviction Decision, all the measures that the Trial Chamber found Mr Bemba could have taken "fell within the scope of the notice provided to Bemba". ${ }^{232}$ The Prosecutor references parts of the Confirmation Decision concerning Mr Bemba's control over the MLC troops, such as: his power to appoint, promote, and dismiss MLC commanders; his power to initiate investigations and prosecutions; his power to arrest; his power to deploy selected battalions to the CAR; the maintenance of contact with the MLC Commander of Operations in the CAR; and the order given by him to withdraw. ${ }^{233}$ The Prosecutor references parts of the Corrected Revised Second Amended Document Containing the Charges that addressed Mr Bemba's control over the MLC troops, including that he controlled recruitment and redistribution of troops; gave instructions for the troops to progress in the field; received daily reports on operations and all matters related to MLC troops; and that he "retained control of MLC forces through his direct involvement in strategic planning and tactical support of field operations". ${ }^{234}$ The Prosecutor notes in particular that Mr Bemba 
"was given notice of the fact that he had the power to 'alter the deployment of troops to minimise contact with civilian populations' [...] through the factual allegation that Bemba deployed the MLC troops in the CAR and that they remained under his effective command and control and that he had the power to withdraw them". 235

144. Mr Bemba in his reply reiterates that "a trier of fact must have regard to what was feasible in the circumstances prevailing at the time". ${ }^{236}$ As to whether he had notice of the Trial Chamber's characterisation of altering the deployment of troops as a "necessary and reasonable measure", Mr Bemba maintains that "minimising contact with the civilian population" is a "specific idea", one not encompassed by his alleged control over the troops, and a finding against which he could not reasonably have known to defend. ${ }^{237} \mathrm{Mr}$ Bemba further argues that the Prosecutor is wrong that at the ad hoc tribunals there was no requirement to list the measures that a commander should have taken. ${ }^{238}$ He states that indictments from the ICTY including the cases of Boškoski and Tarčulovski, Mladić, Halilović, and Hadžihasanović and Kubura listed measures that a commander should have taken because it was part of giving an accused the opportunity to defend himself. ${ }^{239} \mathrm{He}$ argues that the level of detail in the indictments of the ICTR cases are lower as the commanders were often taking no measures or were the perpetrators of the crimes themselves. ${ }^{240}$ Nonetheless, he notes that the judgments did not provide for a list of measures that the accused should have taken, as the Trial Chamber did in this case. ${ }^{241} \mathrm{He}$ further argues that the fact that the Prosecutor listed specific measures in the indictment in this case as well as the Ntaganda case and the Gbagbo case is a strong indicator that specific measures should be listed in the indictment. ${ }^{242}$

\section{(b) The Trial Chamber misappreciated the limitations on the MLC's jurisdiction and competence to investigate}

145. Mr Bemba argues that, having failed to assess his conduct in light of established legal principles, the Trial Chamber was " $[\mathrm{u}]$ nbridled by considerations of what was feasible in the circumstances, [and] viewed Mr. Bemba's ability to investigate in the CAR as being limitless". ${ }^{243} \mathrm{Mr}$ Bemba argues that the Trial Chamber thus erred in not taking into account the limitations on his ability to conduct investigations in the CAR. ${ }^{244}$

146. Mr Bemba maintains that submissions on the obstacles faced by MLC investigations at the time, arising from territorial (i.e. state sovereignty) and jurisdictional limitations, and the difficulties in conducting investigations in a foreign warzone, were unreasonably dismissed or ignored by the Trial Chamber. ${ }^{245} \mathrm{Mr}$ Bemba argues that an investigative mission by the MLC in the CAR would have required assistance from the CAR authorities. ${ }^{246} \mathrm{He}$ submits that such difficulties were also corroborated by witness testimony (from P36 and D48), the Zongo Commission Report and General Seara's Report, all of which indicated that any investigation carried out in the CAR was limited and depended on the cooperation of the CAR authorities. ${ }^{247}$ "The failure to address this evidence and consider the realities on the ground", Mr Bemba argues, affects "the entirety of the Trial Chamber's findings on measures", bearing on its findings that he "failed to initiate genuine and full investigations into the commission of crimes, failed to share relevant information and support investigative efforts, and made no effort to refer the matter to the CAR authorities, or cooperate with international efforts to investigate". 248

147. In response, the Prosecutor argues that the Trial Chamber analysed Mr Bemba's investigative powers reasonably. ${ }^{249}$ She submits that the Trial Chamber "carefully analysed the breadth of [Mr Bemba's] concrete powers to discipline his forces, including any relevant limitations", in arriving at its conclusion that he had "ultimate disciplinary authority over MLC troops in the CAR", and was thus "the competent authority to investigate the crimes and to establish courts-martials". ${ }^{250}$ The Prosecutor avers that this conclusion was bolstered by evidence of the instances in which Mr Bemba exercised disciplinary powers at various times in the CAR: in establishing the Mondonga Inquiry; in dispatching an MLC delegation to Sibut; in court-martialling seven soldiers who were detained in Bangui under Mr Bemba's authority; and broader findings on Mr Bemba's authority over MLC military operations in the CAR. ${ }^{251}$ Furthermore, the Prosecutor argues that the Trial Chamber did not err by not expressly referring to the evidence that $\mathrm{Mr}$ Bemba relies upon to establish that MLC activity in the CAR was limited and reliant on CAR cooperation. ${ }^{252}$ In that regard, the Prosecutor submits that: (i) witness P36's evidence "was immaterial to assessing Mr Bemba's authority over the Mondonga Inquiry in particular or over MLC discipline in the CAR generally"; ${ }^{253}$ (ii) the reference in the Zongo Commission Report to "one interviewee's suggestions that the Mondonga Inquiry included FACA elements [...] had no impact on Mr Bemba's authority" over that Inquiry and need not have been addressed, ${ }^{254}$ (iii) the "Trial 
Chamber expressly relied on D48 to find that Mr Bemba set up the Zongo Commission" and "thus did not fail to consider this evidence", and nor did such evidence establish, in any event, that Mr Bemba lacked the power to investigate MLC crimes in the CAR; ${ }^{255}$ and (iv) the "Trial Chamber reasonably gave no weight to General Seara's evidence and did not err by its approach to his report." 256

\section{(c) The Trial Chamber ignored that Mr Bemba asked the CAR Prime Minister to investigate the allegation}

148. Mr Bemba argues that the Trial Chamber ignored "directly relevant evidence" from D48 that Mr Bemba wrote to the Prime Minister of the CAR, specifically notifying the latter of the allegations of crimes committed by MLC troops. ${ }^{257}$ In this regard, Mr Bemba argues that D48 is a credible witness with direct knowledge of the events, ${ }^{258}$ who testified that Mr Bemba had written to the CAR Prime Minister "asking for an international commission of inquiry to be established to look into these particular events", a course of action that was taken, in the opinion of witness D48, "given that there was an impossible situation to verify what had actually happened in the Central African Republic territory, and they themselves, they had to show diligence in this regard and possibly investigate and pass on the results of the investigation to us". ${ }^{259}$ Moreover, Mr Bemba asserts that D48 recalls the CAR Prime Minister responding, but noted that despite the provision of information, the "did not receive any correspondence or complaints from the CAR authorities". ${ }^{260} \mathrm{Mr}$ Bemba argues that this testimony, from a witness whom the Trial Chamber relied on unreservedly throughout the judgment to support findings adverse to $\mathrm{Mr}$ Bemba, is clearly relevant to refute the finding that Mr Bemba made "no effort to refer the matter to CAR authorities" ${ }^{261}$ Mr Bemba argues that D48's evidence is corroborated by the fact that Mr Bemba corresponded with the UN representative in the CAR and the President of the FIDH, deemed by Mr Bemba to be "better placed to investigate"; ${ }^{262}$ as well as Mr Bemba's contact with the CAR authorities and their involvement in investigating the allegations, referring inter alia to Mr Bemba's meetings with President Patassé. ${ }^{263}$

149. The Prosecutor responds that the "Trial Chamber did not err by not expressly referring to witness D48's evidence" regarding the letter to the CAR Prime Minister given the Trial Chamber's finding that Mr Bemba retained primary authority to sanction MLC troops for their conduct in the CAR and that the CAR authorities "could not have successfully investigated alleged MLC crimes". ${ }^{264}$ The Prosecutor further argues that there is no evidence that the letter to the CAR Prime Minister contained any "concrete information about the MLC crimes of which Mr Bemba knew", thereby not affecting the conclusion of the Trial Chamber that he "failed to share relevant information with the CAR authorities, or to refer the matter to the CAR authorities". ${ }^{265}$ The Prosecutor avers that, in any event, a request by $\mathrm{Mr}$ Bemba to the CAR authorities to set up an international commission of inquiry, as relayed by D48, is similar to the requests he made to the UN and to the FIDH, which did not amount to adequate or genuine measures to address allegations of MLC crimes, especially as there was no evidence that Mr Bemba followed up on these requests, including that to the CAR Prime Minister. ${ }^{266}$ Given that the Trial Chamber found that Mr Bemba had failed to empower MLC officials to "fully and adequately investigate and prosecute allegations of crimes" and could not therefore be said to have submitted the matter to the competent authorities for investigation and prosecution, the Prosecutor argues that the letter to the CAR Prime Minister, which "referred to a potential measure other than empowering the MLC officials", was thus irrelevant. ${ }^{267}$

150. In reply, Mr Bemba contests the Prosecutor's argument that the letter was irrelevant on the ground that it was not the role of the CAR authorities to investigate acts allegedly committed by the MLC, given that the Trial Chamber impugns his failure to refer the matter to the CAR authorities, against which he reiterates his objections. ${ }^{268}$

\section{(d) The Trial Chamber erred in taking into account irrelevant considerations}

151. Mr Bemba argues that "the motivation of a commander in taking measures is irrelevant to the question of whether they were necessary and reasonable". ${ }^{269}$ As such, Mr Bemba argues that the Trial Chamber had regard to irrelevant considerations, in finding that the measures he took were borne out of the "primary motivation" of "a desire to counter public allegations". ${ }^{270}$ Claiming similarity between the measures taken in the CAR and those taken by the President of France at a time when "[t]he reputation of the French Army [wa]s undeniably at stake", ${ }^{271} \mathrm{Mr}$ Bemba asserts that it is undoubtable that the commander-in-chief would seek to preserve the reputation 
of his army, his troops, and the "Republic as a whole" and argues that, should the measures taken in this respect be motivated by the aforementioned desire, "this renders them no less reasonable, and no less necessary" ${ }^{272}$ Moreover, he argues that there are no examples of command cases from the ICTY where the motives for taking measures were ground for liability. ${ }^{273} \mathrm{He}$ maintains that, in fact, the ICTY Appeals Chamber reiterated "the irrelevance and inscrutability of motives in criminal law". ${ }^{274}$ Thus, in Mr Bemba's view, the Trial Chamber's finding that measures taken by a commander are entitled to evidentiary weight only when supported by evidence that "he or she acted with [...] commendable motives is unwarranted by state practice and unsupportable in practice". ${ }^{275} \mathrm{He}$ argues that, nonetheless, the Trial Chamber viewed the measures in light of his motivation and discredited all of the measures that he took. ${ }^{276}$

152. In any event, Mr Bemba avers that such findings of the Trial Chamber of an ulterior motive on his part are unfounded, since, having been based on circumstantial rather than direct evidence, they were not the only reasonable inferences available, as there was evidence showing that "Mr Bemba was motivated by a desire for a disciplined army, and that within the MLC discipline was prioritised". ${ }^{277}$

153. As evidence of his desire for a disciplined army, Mr Bemba cites the testimony of witness P15, who testified that MLC was structured in the same way as a regular army, ${ }^{278}$ and that Mr Bemba "did not tolerate" offences such as rape or murder. ${ }^{279}$ As for evidence of discipline being a priority in the MLC, Mr Bemba cites P15 who stated that, "[g]enerally speaking, as it has been mentioned, discipline was crucial and there were no excesses or aggravated criminal behaviour in the territories controlled by the MLC." $280 \mathrm{He}$ also cites D21 who stated that the attitude of the "political leaders" was that any act that "alienated [the MLC] from the population and its support was to be punished or sanctioned absolutely," and that given the importance of discipline, the MLC had a Code of Conduct ${ }^{281}$ and that "there were mechanisms [...] to inform [the soldiers of] the content of the Code of Conduct." 282 Mr Bemba refers to P36, who stated that "a great deal" of emphasis was put on military discipline and that the soldiers where trained in their duties according to the Code of Conduct. ${ }^{283}$

He cites D39, who testified that there was no policy to attack the civilian population, as they needed to maintain good relations with them and that, with respect to the MLC authorities' attitude towards troops' "misdeeds," "the policy was to punish the soldiers severely." ${ }^{284}$ Mr Bemba also cites D16, who testified that each unit had its own disciplinary council responsible for ensuring that the population was not maltreated, ${ }^{285} \mathrm{D} 49$ who testified about the existence of political commissioners who would disseminate knowledge about the content of the Code of Conduct, ${ }^{286}$ and finally P45 who testified that the duty of the political instructor included teaching the troops about how to treat the civilian population. ${ }^{287}$

154. The Prosecutor responds that the Trial Chamber committed no error as it was apparent from the corroborated evidence that Mr Bemba was motivated to "counter public allegations and [to] rehabilitate the public image of the MLC", and not to genuinely take all necessary and reasonable measures. ${ }^{288}$ The Prosecutor submits that, "having analysed the scope, execution and effect of the measures taken by Bemba, the [Trial] Chamber reasonably concluded that they were 'a grossly inadequate response', were 'not properly and sincerely executed', and were 'not genuine". ${ }^{289}$ Finally, the Prosecutor submits that comparisons made by Mr Bemba to, inter alia, actions of the French President are inapposite and unsupported. ${ }^{290}$

155. The Prosecutor argues that the motives of the superior to take necessary and reasonable measures is not something that must be established in all cases, and can be relevant when assessing the adequacy of the measures taken; ${ }^{291}$ for instance, an enquiry into motives may not be relevant for a commander who has taken all the measures that were necessary and reasonable. ${ }^{292}$ The Prosecutor submits that in the present case, however, Mr Bemba took "minimal, limited and insufficient measures" which thus require an investigation into his motives to "illuminate the genuineness" of the measures taken, and to determine whether the commander took all necessary and reasonable measures within his material possibility. ${ }^{293}$ The Prosecutor states that in the Boškoski and Tarčulovski case, motivations to do more than what was required were deemed irrelevant as the accused had taken necessary and reasonable measures, ${ }^{294}$ whereas in the Strugar case, motivations were found to be relevant in finding that the accused did not take necessary and reasonable measures because he knew that the investigation into his subordinates' crimes was a sham and that it was done as damage control. ${ }^{295}$ The Prosecutor disagrees with Mr Bemba's assertion that he was found liable based on his motivations alone. ${ }^{296}$ She avers that the Trial Chamber first reviewed the measures taken by 
Mr Bemba before reviewing his motivations and concluding that he used minimal and inadequate measures to address the MLC crimes. ${ }^{297}$ Therefore, in her view, the Trial Chamber was reasonable to consider Mr Bemba's motivations together with the evidence of the measures taken to reach its conclusion that he had not taken all necessary and reasonable measures. ${ }^{298}$

156. In reply, Mr Bemba submits that the Prosecutor misinterpreted his argument; he did not argue that the Trial Chamber relied on his motivations alone when finding that he failed to take measures. ${ }^{299}$ He argues that even though his motivation was only one of the factors relied upon, it remains problematic. ${ }^{300} \mathrm{Mr}$ Bemba challenges the Prosecutor's reference to the Strugar case, on the ground that the trial chamber in that case did not use the motivation of the accused to undermine the measures taken, which is the key difference. ${ }^{301} \mathrm{Mr}$ Bemba further argues that General Strugar was found liable on the basis that he did not take any necessary and reasonable measures and not because of his motivations. ${ }^{302}$

157. The Victims argue that the motivation of the commander must be taken into consideration together with the circumstances of the case. ${ }^{303}$ They submit that in the present case, Mr Bemba took a number of steps that were in his own personal interest and the interest of the MLC, rather than to keep crimes from being committed. ${ }^{304}$

\section{(e) The findings on measures taken are unreasonable, misstate the evidence and ignore relevant evidence}

158. Mr Bemba makes a number of submissions on various aspects of the Trial Chamber's findings on the evidence, arguing that the Trial Chamber "disregarded or failed to give a reasoned opinion as to corroborated evidence which cast doubt on its findings, and took into account irrelevant or unreasonable considerations to distort otherwise exculpatory acts and events". 305

159. First, Mr Bemba contends that in its findings on the adequacy of measures he took, the Trial Chamber failed to refer to the agreement between Chad and the CAR to create an international commission of inquiry to investigate allegations of crimes during the 2002-2003 intervention, ${ }^{306}$ whereas it had acknowledged that General Cissé had referred to such an agreement in his response to Mr Bemba's letter requesting UN assistance in conducting an investigation. ${ }^{307} \mathrm{Mr}$ Bemba argues that, since the letter was copied to President Patassé, the latter would have been in a position to have corrected any false impression as to the commission's existence. ${ }^{308} \mathrm{Mr}$ Bemba maintains that the existence of the commission was contextually corroborated by his request to the CAR Prime Minister to establish an international commission of inquiry as relayed by D48, and a February 2003 radio interview during which President Patassé stated that a commission had been sent to investigate allegations of crimes. ${ }^{309} \mathrm{He}$ argues that these factors were not addressed by the Trial Chamber. ${ }^{310}$ "Having been told that two states would initiate an investigation", Mr Bemba argues that "a reasonable commander acting in good faith could justifiably have decided to wait for the outcome of that investigation". ${ }^{111}$ Furthermore, he submits that given General Cissé's assurance that he would "seise the UN Secretary General", a reasonable commander could also expect the UN to provide the MLC with "actionable information upon which further punitive measures could be based". 312

160. Second, Mr Bemba contends that he "did not sit and wait"" and that the Trial Chamber erred in holding that he took no concrete measures, given that he initiated the Sibut Mission and wrote to, and telephoned, the FIDH President. ${ }^{313} \mathrm{He}$ argues that the Trial Chamber's criticism that he took no further concrete measures is "wholly unreasonable, and misstates the evidence". 314 He contests the Trial Chamber's findings that he should have taken concrete measures in light of his correspondence with the President of the FIDH, arguing that the 2003 FIDH report was founded on anonymous hearsay, with the names of all witnesses and sources withheld, no identification of MLC troops, and that no good faith commander could have started arresting people without a reasonable basis. ${ }^{315}$ Furthermore, Mr Bemba states that, since the President of the FIDH provided information to the ICC, not the MLC, he did not have the information needed to take the steps that the Trial Chamber criticized him of not taking. ${ }^{316}$

161. Third, Mr Bemba contends that the Trial Chamber misstated the evidence in finding that the Mondonga Inquiry and Zongo Commission were limited in scope and duration, an inaccurate and unreasonable finding, in that "[a] commander who reacts immediately to crimes cannot then be impugned for the investigation not encompassing future allegations". ${ }^{317}$ As support for the argument that the Mondonga Inquiry continued throughout the 
2002-2003 CAR Operation, he cites the testimony of witness P36 (a witness he maintains the Trial Chamber had deemed credible on the Mondonga Inquiry) who stated that the committee set up by Mr Bemba "did work in Bangui right up until the end, almost to the end of operations". ${ }^{318} \mathrm{Mr}$ Bemba argues that the Trial Chamber's failure to refer to P36's evidence on this point is "particularly egregious", given that his evidence was corroborated by the cover report of the Bomengo case file, which stated that "the operation continues to arrest those who may be involved directly or indirectly". ${ }^{319}$ In relation to the scope of the Mondonga Inquiry, Mr Bemba challenges as "inaccurate and unreasonable" the Trial Chamber's conclusion that the Mondonga Inquiry was limited to allegations of pillaging, contending that the Trial Chamber ignored directly relevant evidence from D19 who testified that Colonel Moustapha was questioned as to rape and killing during the course of the inquiry. ${ }^{320}$

162. Fourth, Mr Bemba contends that the Trial Chamber distorted the evidence of the Sibut Mission. ${ }^{321} \mathrm{He}$ submits that, contrary to the Trial Chamber's findings that the interviewers spoke to a narrow selection of people some of whom were public officials, there was no evidence that MLC officials chose the people to whom they spoke, and that, in any case, speaking with local authorities to get an overview of the situation would be normal (considering that prosecution witnesses who were public officials under General Bozizé, and members of the government of President Kabila were deemed credible). ${ }^{322} \mathrm{Mr}$ Bemba avers that it was "an abuse of the Trial Chamber's discretion" to find that the armed MLC troops created a "coercive atmosphere" during the interviews, given that it was a warzone. ${ }^{323}$

163. The Prosecutor responds that Mr Bemba is simply re-litigating trial arguments and "fails to demonstrate that the Chamber failed to consider relevant evidence or was otherwise unreasonable". ${ }^{324}$ She argues that the Trial Chamber acted reasonably in giving limited weight to evidence that the CAR and Chad had agreed to create an international commission of inquiry (acknowledging that General Cissé had referred to such an agreement in correspondence with Mr Bemba), but "did not find that Bemba was simply allowed to wait for the outcome of a foreign investigation". ${ }^{325}$ The Prosecutor avers that the Trial Chamber found that there was no evidence of any concrete measures taken as a result of their correspondence. ${ }^{326}$ The Prosecutor argues that " $\left.t\right]$ his finding must be viewed together with the Chamber's finding that Bemba - and not the CAR authorities - held and exercised primary disciplinary authority over the MLC contingent in the CAR". ${ }^{327}$

164. The Prosecutor submits that Mr Bemba's reactions to the FIDH Report and the Sibut Mission were grossly inadequate responses to the allegations of MLC crimes ${ }^{328}$ and "[a]ccordingly, the Chamber was accurate when it found that these initiatives did not amount to concrete measures". ${ }^{329}$ Further, the Prosecutor maintains that the Trial Chamber reasonably found the Mondonga Inquiry to be "a grossly inadequate response to the allegations of MLC crimes", arguing that the fact that it "continued until the end of the 2002-2003 CAR Operation demonstrates no error, because there was no evidence that, even at a later stage, it was conducted differently or produced different outcomes". ${ }^{330}$ She asserts that there was similarly no error in the Trial Chamber's finding that the Mondonga Inquiry did not question suspects about murder and did not pursue reports of rape, given that the evidence relied upon by $\mathrm{Mr}$ Bemba was found to be unreliable. ${ }^{331}$ The Prosecutor argues that Mr Bemba simply disagrees with the Trial Chamber's evaluation of the evidence without showing that the Trial Chamber's findings were unreasonable. ${ }^{332}$

165. In reply, Mr Bemba reiterates that there is no requirement under international law to follow-up on measures taken. ${ }^{333} \mathrm{He}$ argues that the "genuineness of a commander's measures cannot be dependent on the reaction of those whom he asks for help". 334

\section{Determination by the Appeals Chamber}

166. As set out above, Mr Bemba raises several arguments against the Trial Chamber's finding that he "failed to take all necessary and reasonable measures within his power to prevent or repress the commission of crimes by his subordinates during the 2002-2003 CAR Operation, or to submit the matter to the competent authorities". ${ }^{335}$ His overall contention is that no reasonable trial chamber could have reached this conclusion. For the reasons that follow, the Appeals Chamber finds, by majority, Judge Monageng and Judge Hofmański dissenting, that the Trial Chamber's finding was indeed unreasonable because it was tainted by serious errors. 
167. The scope of the duty to take "all necessary and reasonable measures" is intrinsically connected to the extent of a commander's material ability to prevent or repress the commission of crimes or to submit the matter to the competent authorities for investigation and prosecution. ${ }^{336}$ Indeed, a commander cannot be blamed for not having done something he or she had no power to do.

168. It follows that an assessment of whether a commander took all "necessary and reasonable measures" will require consideration of what measures were at his or her disposal in the circumstances at the time. This is consistent with international jurisprudence. ${ }^{337}$ An assessment of whether a commander took all "necessary and reasonable measures" must be based on considerations of what crimes the commander knew or should have known about and at what point in time.

169. However, it is not the case that a commander must take each and every possible measure at his or her disposal. Despite the link between the material ability of a commander to take measures (which is directly connected to his or her level of authority) and what he or she might reasonably have been expected to do, it is not the case that a commander is required to employ every single conceivable measure within his or her arsenal, irrespective of considerations of proportionality and feasibility. Article 28 only requires commanders to do what is necessary and reasonable under the circumstances.

170. In assessing reasonableness, the Court is required to consider other parameters, such as the operational realities on the ground at the time faced by the commander. Article 28 of the Statute is not a form of strict liability. Commanders are allowed to make a cost/benefit analysis when deciding which measures to take, bearing in mind their overall responsibility to prevent and repress crimes committed by their subordinates. This means that a commander may take into consideration the impact of measures to prevent or repress criminal behaviour on ongoing or planned operations and may choose the least disruptive measure as long as it can reasonably be expected that this measure will prevent or repress the crimes. There is a very real risk, to be avoided in adjudication, of evaluating what a commander should have done with the benefit of hindsight. Simply juxtaposing the fact that certain crimes were committed by the subordinates of a commander with a list of measures which the commander could hypothetically have taken does not, in and of itself, show that the commander acted unreasonably at the time. The trial chamber must specifically identify what a commander should have done in concreto. Abstract findings about what a commander might theoretically have done are unhelpful and problematic, not least because they are very difficult to disprove. Indeed, it is for the trial chamber to demonstrate in its reasoning that the commander did not take specific and concrete measures that were available to him or her and which a reasonably diligent commander in comparable circumstances would have taken. It is not the responsibility of the accused to show that the measures he or she did take were sufficient.

171. Turning to the case at hand, Mr Bemba submits that the Trial Chamber did not take into account what was feasible and possible for him in the circumstances, given the "unique conditions of this case". ${ }^{338}$ In other parts of his appeal he argues that his case was one of non-linear command, for which there is one sole precedent in the jurisprudence of the ad hoc tribunals. ${ }^{339}$ The Appeals Chamber notes that the Trial Chamber had some regard to Mr Bemba's submissions as to the difficulties he faced in implementing relevant investigatory measures, but found these reasons to be unpersuasive. ${ }^{340}$ In particular, the Trial Chamber noted that Mr Bemba "could and did create commissions and missions in reaction to allegations of crimes, two of which operated on CAR territory at the height of the 2002-2003 CAR Operation". ${ }^{341}$ In finding that Mr Bemba did not adopt all "necessary and reasonable measures" it arrived at this conclusion "in light of his extensive material ability to prevent and repress the crimes". ${ }^{342}$ Nevertheless, while the Trial Chamber's finding in this respect has to be read alongside its earlier findings as to the extensiveness of $\mathrm{Mr}$ Bemba's control over the MLC forces in the CAR, ${ }^{343}$ the Trial Chamber paid insufficient attention to the fact that the MLC troops were operating in a foreign country with the attendant difficulties on Mr Bemba's ability, as a remote commander, to take measures.

172. In this regard, the Appeals Chamber also notes Mr Bemba's argument that the Trial Chamber ignored the testimony of witness P36 demonstrating that the "MLC's investigative efforts were dependent on the Central African authorities for access, movement, and contact with civilians", resulting in the "mixed" composition of the Mondonga Inquiry (i.e. composed of "both people from the Central African Republic and people from the Congo"), ${ }^{344}$ and thus indicative of the fact that Mr Bemba's power to investigate crimes committed in the CAR was limited. Whilst P36's 
testimony does not support the broad proposition that Mr Bemba's material ability to initiate investigations in the CAR was wholly impeded, it demonstrates that the MLC did face logistical difficulties in conducting investigations which had to be overcome (by having a mixed national composition for example). Notably, witness P36 stated that a commission would be comprised of personnel from the CAR as they "would have easier contact with people and they could provide guidance, or they could guide the Congolese persons within the commission with regard to addresses, the language as well, with regards to relations with the other Central Africans, their compatriots". ${ }^{345}$ P36's testimony is supported by the statement found within the Zongo Commission Report, to the effect that the Mondonga Inquiry was mixed in composition. The Appeals Chamber notes that the Trial Chamber did not expressly refer to this aspect of P36's testimony, despite its significance and direct relevance to the issues at hand.

173. Thus, although the limitations alluded to by Mr Bemba did not completely curtail his ability to investigate crimes committed by MLC troops in the CAR, the Trial Chamber did not conduct a proper assessment as to whether, in the particular circumstances that existed at the time, the range of measures taken by Mr Bemba could be regarded as the extent of the necessary and reasonable measures that he could have taken, given the limitations upon his material abilities. The Trial Chamber accepted that the MLC contingent had cooperated with the CAR authorities throughout the 2002-2003 CAR Operation and that such cooperation was both "logical in a situation where a contingent of foreign forces is unfamiliar with the terrain and enemy" and a "regular feature of the operations". ${ }^{346}$ However, in the assessment of the measures that Mr Bemba took, this aspect was disregarded, resulting in an unrealistic assessment of the "wide range of available measures at his disposal". ${ }^{347}$ The Trial Chamber even acknowledged that, in so far as the evidence of witnesses supported the proposition that the CAR authorities had retained "some, but not primary or exclusive," disciplinary or investigative authority over the MLC forces, this was not "inconsistent with the corroborated and reliable evidence that Mr Bemba and the MLC had ultimate disciplinary authority" over the MLC contingent in the CAR. ${ }^{348}$ Moreover, even if Mr Bemba had ultimate disciplinary authority in the CAR, this does not mean that this disciplinary authority was not in any way subject to limitations or impeded to a degree - a reality which the Trial Chamber ought to have given weight in its assessment of the measures that Mr Bemba took.

174. The Appeals Chamber also notes that the Trial Chamber did not address Mr Bemba's statement that he wrote to the CAR Prime Minister requesting an international commission of inquiry to be set up, ${ }^{349}$ nor the testimony of D48 which attested to the existence and content of the letter.

175. The Prosecutor did not contest at trial that Mr Bemba had transmitted a letter to the CAR Prime Minister, nor does she do so on appeal. Instead, the Prosecutor contests the relevance of any such letter, given that the purported measure which Mr Bemba was said to have proposed in that letter was the same as those measures that were discounted by the Trial Chamber, i.e. a commission of inquiry. ${ }^{350}$ In the view of the Appeals Chamber, the Prosecutor's argument as to the eventual outcome of the Trial Chamber's hypothetical consideration of any such letter is clearly speculative. Moreover, in its consideration of the correspondence between Mr Bemba and General Cissé (the UN Representative in the CAR), the Trial Chamber expressly noted that in his response to $\mathrm{Mr}$ Bemba's letter, General Cissé had, inter alia, "recalled that the CAR and Chad had agreed to create an international commission of inquiry". ${ }^{351}$ Given that Mr Bemba had expressly raised before the Trial Chamber the matter of having written to the CAR authorities and the Trial Chamber's eventual finding that Mr Bemba "made no effort to refer the matter to the CAR authorities, or cooperate with international efforts to investigate the crimes", 352 it was imperative that the Trial Chamber address this argument. Furthermore, the possibility that the Trial Chamber may have harboured some doubts as to whether Mr Bemba actually sent the letter was not a sufficient ground for it to disregard an uncontested factual allegation. Indeed, if the accused makes a factual claim that was not challenged by the Prosecutor in the course of the trial, the Trial Chamber must give clear and convincing reasons as to why it nevertheless regards the allegation to be untrue. In the absence of such reasoning, the Trial Chamber was not at liberty to simply ignore Mr Bemba's claim. The Trial Chamber thus erred by failing to take into account relevant considerations.

176. The Appeals Chamber also considers that the Trial Chamber inappropriately took Mr Bemba's motives into consideration when determining whether the measures he had taken were necessary and reasonable. While the Appeals Chamber rejects Mr Bemba's submission that the motives of an accused commander are always irrelevant to the assessment of "necessary and reasonable measures" because a commander is required to act in good faith in adopting such measures and must show that he "genuinely" tried to prevent or repress the crimes in question or 
submit the matter to the competent authorities, ${ }^{353}$ it finds that the Trial Chamber took an unreasonably strict approach.

177. The Trial Chamber found that the measures Mr Bemba took "were primarily motivated by Mr Bemba's desire to counter public allegations and rehabilitate the public image of the MLC". ${ }^{354}$ It further found "that a key intention behind the measures Mr Bemba took was to protect the image of the MLC". 355 The Appeals Chamber accepts Mr Bemba's submission that measures taken by a commander motivated by preserving the reputation of his or her troops do not intrinsically render them any less necessary or reasonable in preventing or repressing the commission of crimes, and ensuring their prosecution after proper investigation. ${ }^{356}$

178. The Appeals Chamber notes that the Trial Chamber's preoccupation with Mr Bemba's motivations appears to have coloured its entire assessment of the measures that he took. Indeed, in assessing the Mondonga Inquiry, the Trial Chamber appears to have considered what it perceived to be Mr Bemba's adverse motivations in establishing the inquiry as a key factor in assessing the genuineness of that measure (namely, countering media allegations, demonstrating the taking of action, vindicating MLC leadership and generally rehabilitating its image). ${ }^{357}$ The Trial Chamber's consideration of Mr Bemba's motivations also significantly affected its finding regarding his correspondence with the UN Representative in the CAR (which was said to have been driven by the desire to demonstrate good faith and maintain the image of the MLC) ${ }^{358}$ and his withdrawal from the CAR (which was said to have been motivated by external pressure directly related to the negotiation of the Sun City agreements). ${ }^{359}$ Ultimately, the Trial Chamber concluded that in fact allof the measures that Mr Bemba had taken in response to allegations of crimes were driven by a motivation to counter public allegations and rehabilitate the public image of the MLC. ${ }^{360}$ Whereas the Trial Chamber stated that these motivations were a factor "aggravating" the failure to exercise his duties, in effect the Trial Chamber appears to have treated the motives as determinative, in and of themselves, of the adequacy or otherwise of the measures. From the ambiguous concept of an "aggravated omission" arises the impression that the Trial Chamber's evaluation of the adequacy of the measures taken by Mr Bemba was tainted by what it considered Mr Bemba's motivations to be.

179. Moreover, the motivations that the Trial Chamber found established, namely, the broad desire to maintain the image of the MLC and counter public allegations are not in fact intrinsically "negative" motivations, as the Trial Chamber appears to have considered them. Nor do they necessarily conflict with the taking of genuine and effective measures. There may be multiple motives behind the measures taken by a commander. In this respect it is conceivable that a commander may discharge his duty to take "necessary and reasonable measures" and in doing so accomplish multiple, additional or extraneous purposes, such as protecting the public image of his forces. Therefore, in considering Mr Bemba's motivation to protect the image of the MLC, the Trial Chamber erred because it took into consideration an irrelevant factor. In any event, the Trial Chamber failed to make an assessment as to how in concreto such alleged motive ultimately affected the necessity or reasonableness of the measures taken by $\mathrm{Mr}$ Bemba.

180. Turning to the remainder of Mr Bemba's arguments, the Appeals Chamber recalls that the Trial Chamber faulted the measures Mr Bemba took because they were limited in "mandate, execution, and/or results". ${ }^{661}$ The Trial Chamber appears to have lost sight of the fact that the measures taken by a commander cannot be faulted merely because of shortfalls in their execution. When a commander establishes an independent commission, inquiry or judicial process - of which he or she is not part - it must be left to freely fulfill its mandate. Whilst limitations in the results of an inquiry might be attributable to the manner of its establishment (for example, through deliberate exclusion or limitation of mandate), this is not necessarily so. It is important to establish, in this regard: (i) that the shortcomings of the inquiry were sufficiently serious; (ii) that the commander was aware of the shortcomings; (iii) that it was materially possible to correct the shortcomings; and (iv) that the shortcomings fell within his or her authority to remedy. The Trial Chamber did not make this assessment in the present case.

181. In finding that there were "indications that all [the] measures were limited in mandate, execution, and/or results", the Trial Chamber implies that this was attributed to Mr Bemba. ${ }^{362}$ However, without undertaking the necessary assessment set out in the preceding paragraph, this could not be made out without a finding that Mr Bemba purposively limited the mandates of the commissions and inquiries. Yet, the Trial Chamber made no such finding as to the sham nature of the measures. 
182. The Trial Chamber also faulted Mr Bemba for having failed to empower other MLC officials to fully and adequately investigate and prosecute allegations of crimes as a result of which he could not be said to have submitted the matter to the competent authorities for investigation and prosecution. ${ }^{363}$ However, the Trial Chamber cited no evidence in support of this finding. In addition, this finding appears to be in contradiction with the Trial Chamber's finding that "Colonel Moustapha and the other MLC Commanders also had some disciplinary authority in the field" ${ }^{364}$ The Trial Chamber failed to explain this apparent contradiction and its finding as to the lack of empowerment of other MLC officials, hence it appears unreasonable. Moreover, given that finding, the Trial Chamber failed to explain what more Mr Bemba should have done to empower other MLC officials to fully and adequately investigate and prosecute allegations of crimes and how he fell short in that regard.

183. Furthermore, it is evident that the assessment of a trial chamber of the measures taken by a commander also depends on the number of crimes that were committed. The Appeals Chamber recalls that the actual number of crimes established beyond reasonable doubt in the instant case was comparatively low. ${ }^{365}$ While the Trial Chamber noted, in relation to the specific locations where crimes had been committed, that there was "reliable evidence" more generally that the MLC committed crimes at these locations, ${ }^{366}$ the evidence in question, on its face, appears for the most part very weak, often consisting of media reports including anonymous hearsay. ${ }^{367}$ Importantly, the Trial Chamber failed to properly analyse this evidence and address its potentially extremely low probative value. The Trial Chamber also failed to give even an indication of the approximate number of crimes that were committed at these locations. Thus, beyond the low number of individual instances of crimes found to have been established beyond reasonable doubt, it is unclear how widespread the criminal behaviour of the MLC troops in the 20022003 CAR Operation was; and, as a corollary, it is difficult to assess the proportionality of the measures taken. Furthermore, the Appeals Chamber notes the apparent discrepancy between the limited number of crimes for which $\mathrm{Mr}$ Bemba was held responsible under article 28 and the Trial Chamber's assessment of the measures Mr Bemba should have taken, which appears to have been based on the much broader and more general 'finding' by the Trial Chamber concerning widespread MLC criminality in the CAR. Indeed, a finding that the measures deployed by a commander were insufficient to prevent or repress an extended crime wave, for example five hundred crimes, does not mean that these measures were also insufficient to prevent or repress the limited number of specific crimes, for example 20 crimes, for which the commander is ultimately convicted.

184. The Appeals Chamber also notes that the majority of the criminal incidents in relation to which the Prosecutor presented evidence occurred at the beginning of the 2002-2003 CAR Operation, whereas little evidence was presented regarding specific criminal acts towards the end of the operation; a factor which must be taken into account when assessing whether Mr Bemba took all necessary and reasonable measures. Whereas it may have been difficult to make a determination as to the actual extent of criminal behaviour, both in terms of number of crimes and duration, the Trial Chamber should at least have acknowledged this challenge and determined its impact on the assessment of the question of whether Mr Bemba took all necessary and reasonable measures. By failing to do so, the Trial Chamber erred.

185. Finally, the Appeals Chamber recalls that the Trial Chamber found that Mr Bemba had failed to take all necessary and reasonable measures, noting inter alia that Mr Bemba should have modified MLC troop deployment so as to, for example, minimise contact with the civilian population, whereas Mr Bemba argues that he did not have sufficient notice of this potential measure.

186. The Appeals Chamber considers it axiomatic that an accused person be informed promptly and in detail of the nature, cause and content of a charge. ${ }^{368}$ In principle, notice containing the details of the charges must be given prior to the start of the trial. ${ }^{369}$ One of the elements of command responsibility under article 28 (a) of the Statute is that the commander must have failed to take "all necessary and reasonable measures within his or her power to prevent or repress [the crimes'] commission or to submit the matter to the competent authorities for investigation and prosecution". It follows that the accused person must be informed of the factual allegations on the basis of which the Prosecutor seeks to establish this element.

187. The Appeals Chamber notes that the Corrected Revised Second Amended Document Containing the Charges did not specifically identify the redeployment of troops as a necessary and reasonable measure that Mr Bemba should have taken. Nor was redeployment of the MLC troops, for example, to minimise contact with the civilian population mentioned in any other document designed to give Mr Bemba notice of the charges as a measure that he should have 
taken. The deployment of troops to the CAR from the DRC was mentioned in the above document only in the context of establishing Mr Bemba's effective control over the MLC forces, ${ }^{370}$ and therefore did not provide adequate notice of redeployment within the CAR and within the particular context of the necessary and reasonable measures taken. Thus, he was not sufficiently notified of this factual allegation as a necessary and reasonable measure.

188. The Appeals Chamber is of the view that Mr Bemba suffered prejudice as a result of the lack of proper notice. The Appeals Chamber notes in this regard Mr Bemba's submission on appeal that, had he known that troop redeployment was considered a necessary and reasonable measure that he should have taken, he would have argued that this would not have been feasible or would have put lives at risk from "friendly fire". ${ }^{371}$ Thus, the Trial Chamber should not have relied on this measure when finding that Mr Bemba had failed to take all necessary and reasonable measures and by doing so the Trial Chamber erred.

189. In sum, the Appeals Chamber has identified the following serious errors in the Trial Chamber's assessment of whether Mr Bemba took all necessary and reasonable measures to prevent or repress the commission of crimes by his subordinates or to submit the matter to the competent authorities for investigation and prosecution: (i) the Trial Chamber erred by failing to properly appreciate the limitations that $\mathrm{Mr}$ Bemba would have faced in investigating and prosecuting crimes as a remote commander sending troops to a foreign country; ${ }^{372}$ (ii) the Trial Chamber erred by failing to address Mr Bemba's argument that he sent a letter to the CAR authorities before concluding that Mr Bemba had not referred allegations of crimes to the CAR authorities for investigation; ${ }^{373}$ (iii) the Trial Chamber erred in considering that the motivations that it attributed to $\mathrm{Mr}$ Bemba were indicative of a lack of genuineness in adopting measures to prevent and repress the commission of crimes; ${ }^{374}$ (iv) the Trial Chamber erred in attributing to $\mathrm{Mr}$ Bemba any limitations it found in the mandate, execution and/or results of the measures taken; ${ }^{375}$ (v) the Trial Chamber erred in finding that Mr Bemba failed to empower other MLC officials to fully and adequately investigate and prosecute crimes; ${ }^{376}$ (vi) the Trial Chamber erred in failing to give any indication of the approximate number of the crimes committed and to assess the impact of this on the determination of whether Mr Bemba took all necessary and reasonable measures; ${ }^{377}$ and (vii) the Trial Chamber erred by taking into account the redeployment of MLC troops, for example to avoid contact with the civilian population as a measure available to $\mathrm{Mr} \mathrm{Bemba.}{ }^{378} \mathrm{The}$ Appeals Chamber shall now assess the cumulative material impact of these errors.

190. In assessing the measures that Mr Bemba took, the Trial Chamber focused on the Mondonga Inquiry (which resulted in the Bomengo case file), the meeting with General Cissé, the UN representative in the CAR, and President Patassé in November 2002, the speech he gave to his troops in November 2002, the Gbadolite court-martial, the Zongo Commission, correspondence with General Cissé, correspondence with the President of the FIDH, and the Sibut Mission. ${ }^{379}$

191. The Appeals Chamber finds that the errors that it has identified have a material impact on the Trial Chamber's finding that Mr Bemba failed to take all necessary and reasonable measures. In particular, it is apparent that the Trial Chamber's error in considering Mr Bemba's motivation had a material impact on the entirety of its findings on necessary and reasonable measures because it permeated the Trial Chamber's assessment of the measures that $\mathrm{Mr}$ Bemba had taken. Furthermore, the Trial Chamber's failure to fully appreciate the limitations that Mr Bemba would have faced in investigating and prosecuting crimes as a remote commander sending troops to a foreign country had an important impact on the overall assessment of the measures taken by Mr Bemba.

192. Indeed, in faulting the results of measures taken by Mr Bemba, the Trial Chamber failed to appreciate that, as a remote commander, Mr Bemba was not part of the investigations and was not responsible for the results generated. Had it done so, the Trial Chamber's assessment of the measures Mr Bemba had taken would have been necessarily different. It must also be noted that the 2002-2003 CAR Operation was conducted within the short space of a few months, which notwithstanding, Mr Bemba took numerous measures in response to crimes committed by MLC troops. In this regard, the Appeals Chamber recalls that the Trial Chamber failed to properly establish how many crimes had been committed.

193. Had the Trial Chamber properly assessed the measures that Mr Bemba took and had the Trial Chamber properly considered the list of measures that it stated that Mr Bemba could have taken in light of the limitations that he faced in the specific circumstances in which he was operating, it would not have been open to it to reach 
the same conclusion. The errors the Trial Chamber made resulted in an unreasonable assessment of whether Mr Bemba failed to take all necessary and reasonable measures in the circumstances existing at the time.

194. In light of the foregoing, the Appeals Chamber finds, by majority, Judge Monageng and Judge Hofmański dissenting, that the Trial Chamber's conclusion that Mr Bemba failed to take all necessary and reasonable measures in response to MLC crimes in the CAR, was materially affected by the errors identified above. Thus, one of the elements of command responsibility under article 28 (a) of the Statute was not properly established and Mr Bemba cannot be held criminally liable under that provision for the crimes committed by MLC troops during the 2002-2003 CAR Operation.

\section{APPROPRIATE RELIEF}

195. In an appeal pursuant to article 81 (1) (b) of the Statute, the Appeals Chamber may confirm, reverse or amend the decision appealed or order a new trial before a different trial chamber (article 83 (2) of the Statute).

196. In the present case, the Appeals Chamber has found, by majority, that the Trial Chamber erred when convicting Mr Bemba for the criminal acts listed above at paragraph 116, as these criminal acts did not fall within the "facts and circumstances described in the charges" in terms of article 74 (2) of the Statute; further, in relation to the remaining criminal acts, the Trial Chamber erred when it found that $\mathrm{Mr}$ Bemba had failed to take all necessary and reasonable measures within his power to prevent or repress the crimes committed by MLC troops during the 20022003 CAR Operation, or to submit the matter to the competent authorities for investigation and prosecution.

197. In these circumstances, the Appeals Chamber considers it appropriate to reverse the conviction of $\mathrm{Mr}$ Bemba and to declare that the criminal acts listed above at paragraph 116 are outside the scope of this case and that the proceedings in that regard are discontinued.

198. In relation to the remainder of the criminal acts of which Mr Bemba was convicted (see above, paragraph 118), it is appropriate to reverse Mr Bemba's conviction and enter an acquittal as the error identified in the Trial Chamber's finding on necessary and reasonable measures extinguishes in full his criminal liability for these crimes.

199. The Appeals Chamber notes that in the case of an acquittal, the acquitted person is to be released from detention immediately. ${ }^{380}$ However, the Appeals Chamber is cognisant of the fact that Mr Bemba was convicted of offences against the administration of justice under article 70 (1) (a) and (c) of the Statute ${ }^{381}$ by this Court in another case. His sentence in relation to that conviction is currently before Trial Chamber VII for a new determination, following the reversal of the original sentence imposed, upon the Prosecutor's successful appeal. ${ }^{382}$

200. Thus, while the Appeals Chamber finds that there is no reason to continue Mr Bemba's detention on the basis of the present case, it rests with Trial Chamber VII to decide, as a matter of urgency, whether Mr Bemba's continued detention in relation to the case pending before it is warranted. ${ }^{383}$

Judge Monageng and Judge Hofmański append a dissenting opinion to this judgment as to the outcome and the reasons therefor. Judge Van den Wyngaert and Judge Morrison append a joint separate opinion to this judgment. Judge Eboe-Osuji will append a separate opinion to this judgment, which will be filed in due course.

Done in both English and French, the English version being authoritative.

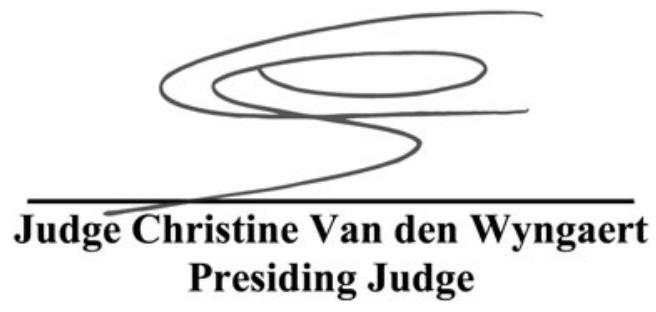

Dated this $8^{\text {th }}$ day of June 2018

At The Hague, The Netherlands 


\section{ENDNOTES}

1 Conviction Decision, paras 741-742, 752.

2 Conviction Decision, para. 1.

3 Conviction Decision, para. 2.

4 Conviction Decision, para. 380.

5 "Defence Notice of Appeal against the Judgment pursuant to Article 74 of the Statute, ICC-01/05-01/08-3343", ICC-01/ 05-01/08-3348.

6 Appeal Brief.

7 Additional Evidence Application.

8 Response to the Appeal Brief.

9 Prosecutor's Response to the Additional Evidence Application.

10 Reply to the Prosecutor's Response to the Additional Evidence Application.

11 Reply to the Response to the Appeal Brief.

12 Victims' Observations on the Additional Evidence Application.

13 Victims' Observations.

14 Reply to the Victims' Observations.

15 Order for Submissions on Contextual Elements.

16 Scheduling Order.

17 Contextual Elements Submissions.

18 Response to Contextual Elements Submissions.

19 Order on the Conduct of the Hearing. The following questions were put to the parties and participants: Group $\boldsymbol{A}$ - Preliminary issues (a. What level of deference should the Appeals Chamber accord to the Trial Chamber's factual findings?; b. Article 81 (1) (b) of the Statute reads in its relevant part: "The convicted person, or the Prosecutor on that person's behalf, may make an appeal on any of the following grounds: [...] (iv) Any other ground that affects the fairness or reliability of the proceedings or decision". Can the convicted person appeal on a ground that affects the fairness of $t$ he proceedings, but does not affect the reliability of the decision?); Group B - Issues relating to the Second Ground of Appeal (a. What are "the facts and circumstances described in the charges", within the meaning of article 74 (2) of the Statute? In particular, which of the following examples is a "fact": (i) the rape of P22 in PK12 on or around 6 or 7 November 2002, or (ii) rape committed by the MLC soldiers in the Central African Republic between on or about 26 October 2002 and 15 March 2003?; b. What is the minimum level of detail required for "[a] statement of the facts" to be included in the document containing the charges pursuant to regulation 52 (b) of the Regulations of the Court, especially regarding "the time and place of the alleged crimes"? Does the required detail depend on the form of individual criminal responsibility charged in the case? In particular, would the required detail in a case of criminal responsibility as a co-perpetrator under article 25 (3) (a) differ from the required detail in a case of command responsibility under article 28 (a) of the Statute?; c. Must acts underlying the crimes charged be exhaustively listed in the document containing the charges?; d. Must the Pre-Trial Chamber determine whether there is sufficient evidence to support, to the requisite standard, each underlying act (a criminal act underlying one of the crimes charged) included in the document containing the charges and enter a finding on each such act in the confirmation decision?; e. Can the Prosecutor notify the accused person of other underlying acts in auxiliary documents provided after the confirmation decision was rendered, without seeking to add additional charges under article 61 (9) of the Statute? Can the accused person be notified of other underlying acts through the provision of statements of victims? If the Prosecutor or the legal representative of victims notifies the accused person of other underlying acts after the confirmation decision, do they exceed "the facts and circumstances described in the charges"?); Group C - Issues relating to the Third Ground of Appeal (a. Would a change from the "knew" standard to the "should have known" standard in article 28 (a) (i) of the Statute amount to a modification of the legal characterisation of the facts, which would need to comply with the requirements of regulation 55 of the Regulations of the Court (including that it not exceed the facts and circumstances of the charges)?; b. Does the Appeals Chamber have the power to change the legal characterisation of the facts itself? (i) If it does not have such power, why is this the case?; (ii) If it does have the power to re-characterise, on what legal basis may it do so?; (iii) To what extent is it relevant that the Trial Chamber gave notice under regulation 55 (2) in the course of the trial?; c. How must the "knew" standard be interpreted? To what extent is the definition of knowledge in article 30 (3) of the Statute relevant to article 28 (a) (i) of the Statute?; d. How must the "should have known" standard be interpreted? Does the "should have known" standard differ materially from the "had reason to know" standard in article 7 (3) of the ICTY Statute and in its jurisprudence? How does this standard relate to the "consciously disregarded" standard in article 28 (b) (i) of the Statute?); Group D - Further issues relating to the Third Ground of Appeal (a. To what extent is a commander's motivation for taking necessary and reasonable measures of relevance in the assessment of their adequacy?; b. Must the accused be given notice of the measures which the Trial Chamber finds he could have taken as a commander? If so, how must such notice be given - must it be given specifically with respect to measures or may it be given in the course of pleadings on the commander's material ability?; c. $\mathrm{Mr}$ Bemba argues that causation is required in the context of article 28 (a) of the Statute, whilst the Prosecutor argues that causation is not required. If causation is required pursuant to article 28 (a) of the Statute, what degree of nexus is required - "but-for", "high probability", "reasonable foreseeability" or other?; d. Does an assessment of causation overlap with an assessment of whether a commander has taken necessary and reasonable measures or is an additional element required?; e. Is a commander under a legal duty to withdraw his troops in the event that he becomes aware that they are committing crimes? If so: (i) What is the legal basis for this duty?; (ii) When does this duty arise?; (iii) Would it extend to all troops or only to those alleged to have committed crimes?; (iv) Is it of any import that withdrawal, either full or partial, would, in all likelihood, lead to military defeat?); Group $\boldsymbol{E}$ Issues relating to the Fourth Ground of Appeal (a. The elements of crimes against humanity include the requirement that "[t]he perpetrator knew that the conduct was part of or intended the conduct to be part of a widespread or systematic attack directed against a civilian population". In cases of 
individual criminal responsibility under article 28 of the Statute, does this requirement apply to the direct perpetrator of the crime or to the accused person or both?; b. Can a Trial Chamber rely on the war crime of pillaging to establish that there was an organizational policy?; c. Responses to and/or replies to responses to the questions listed in the Appeals Chamber's Order for Submissions on Contextual Elements).

Victims' Observations on Contextual Elements.

Mr Bemba's Response to Victims' Observations on Contextual Elements.

Appeals Hearing Transcript 9 January 2018; Appeals Hearing Transcript 10 January 2018; Appeals Hearing Transcript 11 January 2018.

Appeals Hearing Transcript 11 January 2018, p. 88, lines 18 25 .

Mr Bemba's Submissions further to the Hearing; Prosecutor's Submissions further to the Hearing; Victims' Submissions further to the Hearing.

Appeals Hearing Transcript 9 January 2018, p. 2, lines 5-22; Appeals Hearing Transcript 10 January 2018, p. 25 line 23.

Request to File an Additional Authority, paras 2-3.

Response to Request to File an Additional Authority, para. 7.

Appeal Brief, paras 13-114.

Appeal Brief, paras 115-128.

Appeal Brief, paras 129-413.

Appeal Brief, paras 414-461.

Appeal Brief, paras 462-493.

Appeal Brief, paras 494-546.

Appeal Brief, paras 129-226.

Appeal Brief, paras 227-286.

Appeal Brief, paras 287-324.

Appeal Brief, paras 325-380.

Appeal Brief, paras 381-413.

See infra, paras 38 et seq, para. 66.

Lubanga Appeal Judgment, paras 18-19; Ngudjolo Appeal Judgment, para. 20.

Lubanga Appeal Judgment, para. 27.

Lubanga Appeal Judgment, para. 21 (footnotes omitted). See also Ngudjolo Appeal Judgment, para. 22.

Lubanga Appeal Judgment, para. 24.

See Lubanga Appeal Judgment, para. 27.

Lubanga Appeal Judgment, para. 22.

Bemba et al. Appeal Judgment, para. 868.

Nuon Chea and Khieu Samphân Appeal Judgment, para. 90.

Lubanga Appeal Judgment, para 20; Ngudjolo Appeal Judgment, para. 21 .

Ngudjolo Appeal Judgment, para. 21.

Kenyatta OA5 Judgment, para. 22. See also Kony et al. OA3 Judgment, paras 79-80; Ruto et al. OA Judgment, paras 8990; Lubanga Sentencing Appeal Judgment, para. 41.

See for example, Appeal Brief, paras 162, 167, 170, 206, 228, 427, 431, 432, 442, 468, 509.

52 Lubanga OA5 Judgment, para. 20, referring to Hadjianastassiou v. Greece, para. 32.

53 Lubanga OA5 Judgment, para. 20.

54 See, with respect to appeals filed under rules 154 and 155 of the Rules, Lubanga OA5 Judgment, para. 20; Bemba et al. OA4 Judgment, para. 116.

55 See article 83 (2) (b) of the Statute.

56 See article 83 (2), second sentence, of the Statute.

57 The Appeals Chamber notes that the Appeals Chamber of the ICTY has adopted the same approach. See Perišić Appeal Judgment, para. 96; Gotovina and Markač Appeal Judgment, para. 64.

58 Mr Bemba: Appeals Hearing Transcript 9 January 2018, p. 10, line 20 to p. 12, line 5; p. 12, lines 9-23; p. 24, lines 17-24. The Prosecutor: Appeals Hearing Transcript 9 January 2018, p. 17, lines 11-18; p. 19, lines 4-20, referring to Lubanga Apeal Judgment, paras 56, 155. Also referring to $C D F$ Appeal Judgment, para. 35; RUF Appeal Judgment, para. 34, stating that "Only errors that occasion a miscarriage of justice would vitiate the proceedings. Such are procedural errors that would affect the fairness of the trial. By the same token, procedural errors that could be waived or ignored (as immaterial or inconsequential) without injustice or prejudice to the parties would not be regarded as procedural errors occasioning a miscarriage of justice."; Appeals Hearing Transcript 9 January 2018, p. 19, lines 9-20.

59 The French version of the same passage reads: "la procédure faisant l'objet de l'appel est viciée au point de porter atteinte à la régularité de la décision ou de la condamnation".

60 Lubanga Appeal Judgment, para. 28.

61 Lubanga Appeal Judgment, para. 30 (footnotes omitted).

62 Lubanga Appeal Judgment, para. 31.

63 Lubanga Appeal Judgment, paras 30, 33, referring to Kony et al. OA3 Judgment, para. 48, which reads, in relevant part: "as part of the reasons in support of a ground of appeal, an appellant is obliged not only to set out the alleged error, but also to indicate, with sufficient precision, how this error would have materially affected the impugned decision". See also Ngudjolo Appeal Judgment, para. 205 ("The Appeals Chamber finds that, at best, the Prosecutor is putting forward a possible alternative interpretation of the evidence, but she has failed to establish any error on the part of the Trial Chamber that would render the Chamber's approach unreasonable. Accordingly, the Prosecutor's arguments are rejected").

64 Mr Bemba: Appeal Brief, paras 7-10; Appeals Hearing Transcript 9 January 2018 , p. 4, line 13-15; p. 5, line 4 to p. 10, line 19; Mr Bemba's Submissions further to the Hearing, paras 3, 7-8. The Prosecutor: Appeals Hearing Transcript 9 January 2018, p. 13, line 11 to p. 16, line 20; Response to the Appeal Brief, para. 4. Victims: Appeals Hearing Transcript 9 January 2018, p. 21, line 22 to p. 22 line 24.

65 Mr Bemba: Appeal Brief, paras 7-10; Appeals Hearing Transcript 9 January 2018 , p. 4, line $13-15$; p. 5 , line 4 to p. 10, line 19; Mr Bemba's Submissions further to the Hearing, paras 3, $7-8$.

66 Additional Evidence Application, para. 12.

67 Additional Evidence Application, para. 14.

68 Request to File an Additional Authority, paras 2-3. 
Response to Request to File an Additional Authority, para. 7.

Appeal Brief, para. 115.

Appeal Brief, para. 115.

Appeal Brief, paras 122-123.

Amended Document Containing the Charges, pp. 33-37.

Confirmation Decision,; para. 140: "Having reviewed the Disclosed Evidence as a whole, the Chamber finds that MLC soldiers killed civilians during the attack directed against the CAR civilian population carried out from on or about 26 October 2002 until 15 March 2003, thus committing crimes against humanity within the meaning of article 7(1)(a) of the Statute". Confirmation Decision, para. 277: "Having reviewed the Disclosed Evidence as a whole, the Chamber finds that, as MLC soldiers moved in battle throughout the CAR, they killed civilians thus committing war crimes according to article 8(2) (c)(i) of the Statute".

Confirmation Decision, para. 160: "The Chamber finds that there is sufficient evidence to establish substantial grounds to believe that acts of rape constituting crimes against humanity directed against CAR civilians were committed by MLC soldiers as part of the widespread attack against the CAR civilian population from on or about 26 October 2002 to 15 March 2003, with the knowledge of the attack by MLC soldiers". Confirmation Decision, para. 282: "Having reviewed the Disclosed Evidence as a whole, the Chamber finds that there is sufficient evidence to establish substantial grounds to believe that in the context of and in association with the armed conflict not of an international character on the territory of the CAR, acts of rape constituting war crimes pursuant to article $8(2)(\mathrm{e})(\mathrm{vi})$ of the Statute were committed on civilians by MLC soldiers from on or about 26 October 2002 to 15 March 2003".

6 Confirmation Decision, para. 322: "Having reviewed the Disclosed Evidence as a whole, the Chamber finds that the evidence shows that, as MLC soldiers moved in battle from on or about 26 October 2002 to 15 March 2003 throughout the CAR territory, they appropriated for their own private or personal use belongings of civilians, such as their livestock, vehicles, televisions, radios, clothing, furniture and money, without the consent of the rightful owners".

Confirmation Decision, paras 140, 170, 277, 323.

Transcript of 7 October 2009, ICC-01/05-01/08-T-14-Eng, p. 13, lines 5-10.

Second Amended Document Containing the Charges.

Mr Bemba's Challenge to the Second Amended Document Containing the Charges, para. 36. In the confidential ex parte annex to this submission, Mr Bemba appears to have limited his argument regarding the use of the words "including but not limited to" to the introduction of additional underlying acts of pillaging (see ICC-01/05-01/08-694-Conf-Exp-AnxA, pp. 38-40).

Decision on Mr Bemba's Challenge to the Second Amended Document Containing the Charges, para. 37.

Decision on Mr Bemba's Challenge to the Second Amended Document Containing the Charges, para. 35.

Decision on Mr Bemba's Challenge to the Second Amended Document Containing the Charges, para. 279.

See Second Amended Document Containing the Charges, paras 50, 53-57: rape of unidentified victims 1-8 (para. 55), rape of unidentified victims 9-30 (para. 56), rape of unidentified victims 31-35 (para. 57)); rape of P68 and pillaging of P68's belongings (para. 50, pp. 36, 38). Decision on $\mathrm{Mr}$ $\mathrm{B}$ emb a 's Chal len ge to the Sec o nd Ame nd ed Do cu me nt Co nt aini ng t he $\mathrm{C}$ har ges, paras 107, 110, 113.

85 Corrected Revised Second Amended Document Containing the Charges.

86 Conviction Decision, para. 48, referring to Prosecutor's Closing Brief, paras 310-314, 380-385, 436-442, 494-497.

87 Conviction Decision, para. 32.

88 Conviction Decision, para. 32.

89 Conviction Decision, para. 42.

90 Conviction Decision, para. 33.

91 Conviction Decision, para. 43.

92 Conviction Decision, paras 44, 49 (a), (b), (c), (d), (e), (f), (j).

93 Conviction Decision, paras 45-46, 49 (a), (g), (h), (i).

94 Conviction Decision, paras 47, 49 (e), (k), (l), (m), (n), (o), (p), (q).

95 Conviction Decision, paras 48, 49 (r), (s), (t).

96 Conviction Decision, para. 49.

97 Conviction Decision, para. 50.

98 Conviction Decision, para. 50.

99 Conviction Decision, para. 50.

100 Appeal Brief, paras 116-121.

101 Appeal Brief, paras 122-123.

102 Appeal Brief, paras 124-128.

103 Appeal Brief, paras 116-117.

104 Appeal Brief, para. 117.

105 Appeal Brief, para. 118.

106 Appeal Brief, para. 118.

107 Appeal Brief, para. 119.

108 Appeal Brief, para. 121 (footnote omitted).

109 Appeal Brief, para. 122.

110 Appeal Brief, para. 123.

111 Appeal Brief, para. 124.

112 Appeal Brief, para. 125.

113 Appeal Brief, para. 126.

114 Appeal Brief, para. 126.

115 Appeal Brief, para. 127.

116 Appeal Brief, para. 127.

117 Appeals Hearing Transcript 9 January 2018, p. 45, lines 1-2. See also p. 44, line 23 to p. 45, line 4, referring to Gbagbo Adjournment Decision, para. 21.

118 Appeals Hearing Transcript 9 January 2018, p. 46, lines 1721.

119 Appeals Hearing Transcript 9 January 2018, p. 46, line 22 to p. 47 , line 1 .

120 Appeals Hearing Transcript 9 January 2018, p. 47, lines 5-17.

121 Appeals Hearing Transcript 9 January 2018, p. 48, lines 5-7.

122 Appeals Hearing Transcript 9 January 2018, p. 49, line 25 to p. 50 , line 2 . 
Appeals Hearing Transcript 9 January 2018, p. 50, line 25 to p. 51 , line 7 .

124 Mr Bemba's Submissions further to the Hearing, para. 23. See also para. 24. Mr Bemba's Submissions further to the Hearing, paras 19-20. Response to the Appeal Brief, paras 78, 84 . Response to the Appeal Brief, para. 83. See also para. 91. Response to the Appeal Brief, paras 78, 84-87.

Response to the Appeal Brief, para. 84. Response to the Appeal Brief, para. 88. Response to the Appeal Brief, para. 91. Response to the Appeal Brief, para. 92. Response to the Appeal Brief, para. 93. Response to the Appeal Brief, para. 93. Response to the Appeal Brief, para. 96. See also paras 95-97, 99

Response to the Appeal Brief, para. 100 Response to the Appeal Brief, paras 104-106. Response to the Appeal Brief, paras 105-106.

Appeals Hearing Transcript 9 January 2018, p. 52, line 24 to p. 53, line 4 .

Appeals Hearing Transcript 9 January 2018, p. 53, lines 7-9. Appeals Hearing Transcript 9 January 2018, p. 54, lines 18 20, referring to Conviction Decision, paras 622, 632, 639 . See also Appeals Hearing Transcript 9 January 2018, p. 84, lines 8-11.

Appeals Hearing Transcript 9 January 2018, p. 78, lines 2-4. Appeals Hearing Transcript 9 January 2018, p. 55, lines 4-6. Appeals Hearing Transcript 9 January 2018, p. 59, lines 1-11. Reply to the Response to the Appeal Brief, para. 24.

Reply to the Response to the Appeal Brief, para. 24.

Victims' Observations, para. 36. Victims' Observations, paras 37-38.

Victims' Observations, para. 40.

Victims' Observations, para. 42.

Victims' Observations, para. 47.

Victims' Observations, para. 48.

Reply to the Victims' Observations, para. 31.

Reply to the Victims' Observations, para. 32.

Reply to the Victims' Observations, para. 33.

It is noted that both Mr Bemba and the Prosecutor misrepresent the Trial Chamber's findings in this regard. Contrary to what Mr Bemba (Appeal Brief, para. 118) and the Prosecutor (Response to the Appeal Brief, paras 83, 91) assert, in its determination of the scope of the charges, the Trial Chamber did not examine whether sufficient notice was given with respect to specific criminal acts. Rather, it first examined whether the specific criminal acts fell within the parameters of the charges set out in the Confirmation Decision and only when satisfied that they did, the Trial Chamber proceeded to examine whether Mr Bemba had received sufficient notice (Conviction Decision, paras 32, 49).

157

158

159

160

161 Conviction Decision, paras 624 (acts of murder); 633 (acts of rape); 640 (acts of pillaging).

162 See supra paras 102-103.

163 Appeals Hearing Transcript 9 January 2018, p. 52, line 24 to p. 53 , line 4 .

164 Appeals Hearing Transcript 9 January 2018, p. 53, lines 7-9.

165 See Confirmation Decision, pp. 184-185, para. d).

166 Amended Document Containing the Charges, pp. 33-34.

167 See Amended Document Containing the Charges, pp. 34, 36-37.

168 Amended Document Containing the Charges, pp. 33-34, 3637; Confirmation Decision, paras 140, 144, 146-150, 152$158,165,169,171-185,277-279,286-288,322,324-329$, $337-338$.

169 Conviction Decision, para. 44.

170 Appeal Brief, paras 124-128.

171 See Confirmation Decision, paras 65-66.

172 Confirmation Decision, paras 169, 338.

173 Conviction Decision, paras 45-46, referring to, inter alia, Confirmation Decision, para. 338.

174 See supra para. 79.

175 See supra paras 29-34.

176 Conviction Decision, paras 197-198.

177 Conviction Decision, para. 719.

178 See Conviction Decision, para. 582.

179 See Conviction Decision, paras 268, 586.

180 Conviction Decision, paras 711-712.

181 Conviction Decision, paras 590-591.

182 Conviction Decision, para. 594.

183 Conviction Decision, paras 600, 712.

184 Conviction Decision, paras 602-603.

185 Conviction Decision, para. 723.

186 Conviction Decision, paras 600, 610-611.

187 Conviction Decision, para. 715, 725.

188 Conviction Decision, para. 720.

189 As to the contents of the letter to General Cissé, see Conviction Decision, para. 605 (footnotes omitted).

190 Conviction Decision, para. 606.

191 Conviction Decision, para. 607.

192 Conviction Decision, para. 609, referring to EVD-T-OTP00832/CAR-OTP-0013-0106 at 0109.

193 Conviction Decision, para. 610.

194 Conviction Decision, para. 611.

195 Conviction Decision, paras 589, 720.

196 Conviction Decision, paras 601-602, 722.

197 Conviction Decision, para. 725. 
198 Conviction Decision, para. 727.

199 Conviction Decision, para. 728.

200 Conviction Decision, para. 728.

201 Conviction Decision, para. 582.

202 Conviction Decision, para. 604.

203 Conviction Decision, paras 555, 730.

204 Conviction Decision, para. 729.

205 Conviction Decision, para. 730.

206 Conviction Decision, para. 732.

207 Conviction Decision, para. 732.

208 Conviction Decision, para. 732.

209 Conviction Decision, para. 734. See also para. 733.

210 Appeal Brief, para. 338.

211 Appeal Brief, para. 339.

212 Appeal Brief, para. 340.

213 Appeal Brief, para. 341.

214 Appeal Brief, para. 328.

215 Appeal Brief, para. 342.

216 Appeals Hearing Transcript 10 January 2018, p. 58, lines 11-15; p. 121, line 18 to p. 122 , line 3 .

217 Appeals Hearing Transcript 10 January 2018, p. 121, lines 8-16.

218 Appeals Hearing Transcript 10 January 2018, p. 76, lines 12-14.

219 Appeal Brief, paras 343-344; Appeals Hearing Transcript 10 January 2018, p. 59, lines 4-15.

220 Appeal Brief, para. 343.

221 Appeals Hearing Transcript 10 January 2018, p. 59, lines 16-24.

222 Appeals Hearing Transcript 10 January 2018, p. 58 line 16 to p. 59 line 3.

223 Response to the Appeal Brief, para. 197 (emphasis in original).

224 Response to the Appeal Brief, para. 203.

225 Response to the Appeal Brief, para. 197.

226 Prosecutor's Submissions further to the Hearing, para. 9

227 Appeals Hearing Transcript 10 January 2018, p. 73, lines $12-15$

228 Appeals Hearing Transcript 10 January 2018, p. 73, lines 21-23; p. 74, lines 12-14.

229 Appeals Hearing Transcript 10 January 2018, p. 73, line 15 to p. 74, line 6 .

230 Appeals Hearing Transcript 10 January 2018, p. 122, lines 6-19.

231 Appeals Hearing Transcript 10 January 2018, p. 122, lines 18-23.

232 Response to the Appeal Brief, para. 202; Appeals Hearing Transcript 10 January 2018, p. 123, line 3.

233 Response to the Appeal Brief, fn. 743, referring to Confirmation Decision, paras 457, 460-464, 474, 477.
234 Response to the Appeal Brief, fn. 744, referring to Corrected Revised Second Amended Document Containing the Charges, paras 22-31, 58-71.

235 Response to the Appeal Brief, fn. 745.

236 Reply to the Response to the Appeal Brief, para. 38.

237 Reply to the Response to the Appeal Brief, para. 39, referring to Appeal Brief, paras 343-344.

238 Appeals Hearing Transcript 10 January 2018, p. 94, lines 21-23.

239 Appeals Hearing Transcript 10 January 2018, p. 94, line 21 to p. 95, line 5, referring to Ha lilo vić Indictment; Hadžihasanović and Kubura Third Amended Indictment; Boškoski and Johan Tarčulovski; Amended Indictment, paras 15-17; Mla $d$ ić Fourth Amended Indictment.

240 Appeals Hearing Transcript 10 January 2018, p. 95, lines $11-15$.

241 Appeals Hearing Transcript 10 January 2018, p. 95, lines 16-20.

242 Appeals Hearing Transcript 10 January 2018, p. 95, line 22 to p. 96 , line 2 .

243 Appeal Brief, paras 345, 355.

244 Appeal Brief, paras 345-354.

245 Appeal Brief, paras 346, 353.

246 Appeal Brief, paras 347-348.

247 Appeal Brief, paras 348-353.

248 Appeal Brief, para. 354 (footnotes omitted).

249 Response to the Appeal Brief, para. 204.

250 Response to the Appeal Brief, para. 204 (footnotes omitted).

251 Response to the Appeal Brief, para. 205. The Prosecutor argues that the Trial Chamber's specific finding on $\mathrm{Mr}$ Bemba's disciplinary power is based on the Trial Chamber's "broader findings". See Response to the Appeal Brief, para. 205, referring to Conviction Decision at paras 382-403, 427-447, 449.

252 Response to the Appeal Brief, para. 206.

253 Response to the Appeal Brief, para. 206.

254 Response to the Appeal Brief, para. 206.

255 Response to the Appeal Brief, para. 206 (emphasis in original omitted).

256 Response to the Appeal Brief, para. 206 (footnotes omitted).

257 Appeal Brief, paras 357, 360.

258 Appeal Brief, paras 356, 359.

259 Appeal Brief, para. 357, referring to Transcript of 6 November 2012, ICC-01/05-01/08-T-267-Red2-Eng, p. 55, lines 7-10.

260 Appeal Brief, para. 358.

261 Appeal Brief, para. 359-360.

262 Appeal Brief, para. 359, referring to Conviction Decision, paras 604-606, 610-611.

263 Appeal Brief, para. 359, referring to Conviction Decision, paras 582-591, 604-606, 610-611.

264 Response to the Appeal Brief, paras 207-208.

265 Response to the Appeal Brief, para. 210. 
266 Response to the Appeal Brief, para. 211, referring to Transcript of 6 November 2012, ICC-01/05-01/08-T-267-Red2Eng, p. 51, lines 2-8.

267 Response to the Appeal Brief, para. 209.

268 Reply to the Response to the Appeal Brief, para. 40.

269 Appeal Brief, para. 361.

270 Appeal Brief, para. 361.

271 Appeal Brief, para. 363.

272 Appeal Brief, paras 362-363.

273 Appeals Hearing Transcript 10 January 2018, p. 57, lines 13-20.

274 Appeals Hearing Transcript 10 January 2018, p. 57, lines 17-20.

275 Mr Bemba's Submissions further to the Hearing, para. 28.

276 Appeals Hearing Transcript 10 January 2018, p. 57, line 11 to p. 58, line 3, referring to Conviction Decision, para. 728 .

277 Appeal Brief, para. 364, referring to Transcript of 31 January 2012, ICC-01/05-01/08-T-202-Red2-Eng, p. 39, lines 14-18; Transcript of 7 February 2012, ICC-01/05-01/08-T-207Red2-Eng, p. 48, lines 5-6; Transcript of 10 February 2012, ICC-01/05-01/08-T-210-Red2-Eng, p. 43, lines 21-25; p. 44, lines 7-8; Transcript of 13 March 2012, ICC-01/05-01/08-T213-Red2-Eng, p. 51, lines 8-20; Transcript of 19 November 2012, ICC-01/05-01/08-T-270-Red2-Eng, p. 43, lines 1-7; Transcript of 26 November 2012, ICC-01/05-01/08-T-275Red2-Eng, p. 21, lines 16-22; Transcript of 8 April 2013, ICC-01/05-01/08-T-301-Red2-Eng, p. 36, line 9 to p. 37, line 3; p. 43, lines 9-19; Transcript of 22 April 2013, ICC01/05-01/08-T-308-Red2-Eng, p. 50, line 5 to p. 51, line 4.

278 Appeal Brief, para. 364, referring to Transcript of 7 February 2012, ICC-01/05-01/08-T-207-Red2-Eng, p. 48, lines 5-6.

279 Appeal Brief, para. 364, referring to Transcript of 10 February 2012, ICC-01/05-01/08-T-210-Red2-Eng, p. 43, lines 21-25.

280 Appeal Brief, para. 364, referring to Transcript of 10 February 2012, ICC-01/05-01/08-T-210-Red2-Eng, p. 44, lines 7-8.

281 Appeal Brief, para. 364, referring to Transcript of 8 April 2013, ICC-01/05-01/08-T-301-Red2-Eng, p. 36, line 9 to p. 37 , line 3 .

282 Appeal Brief, para. 364, referring to Transcript of 8 April 2013, ICC-01/05-01/08-T-301-Red2-Eng, p. 43, lines 9-19.

283 Appeal Brief, para. 364, referring to Transcript of 13 March 2012, ICC-01/05-01/08-T-213-Red2-Eng, p. 51, lines 8-20.

284 Appeal Brief, para. 364, referring to Transcript of 22 April 2013, ICC-01/05-01/08-T-308-Red2-Eng, p. 50, line 5 to p. 51 , line 4 .

285 Appeal Brief, para. 364, referring to Transcript of 26 November 2012, ICC-01/05-01/08-T-275-Red2-Eng, p. 21, lines $16-22$.

286 Appeal Brief, para. 364, referring to, Transcript of 19 November 2012, ICC-01/05-01/08-T-270-Red2-Eng, p. 43, lines 1-7.

287 Appeal Brief, para. 364, referring to, Transcript of 31 January 2012, ICC-01/05-01/08-T-202-Red2-Eng, p. 39, lines 14-18.

288 Response to the Appeal Brief, para. 212, referring to Conviction Decision, para. 728.

289 Response to the Appeal Brief, para. 212 (footnotes omitted), referring to Conviction Decision, paras 574-620, 720-727.
290

291

292

\section{3}

\section{4}

\section{5}

296

297

298

March 2012 ICC-01/05-01/08-T-215-Red2-Eng, p. 6, lines 21-24 (Q. How long did this fact-finding committee conduct its investigation? A. I couldn't tell you exactly how long it was. One or two weeks, perhaps a month, but I do know that the committee that was set up by Jean-Pierre Bemba did work in Bangui right up until the end, almost to the end of operations.)

319 Appeal Brief, para. 373, referring to EVD-T-OTP-00393/ CAR-DEF-0002-0001.

320 Appeal Brief, paras 374, referring to Transcript of 26 February 2013, ICC-01/05-01/08-T-285-Red2-Eng, p. 42, lines 6-11.

321 Appeal Brief, para. 376. 
Appeal Brief, paras 377-378.

Appeal Brief, para. 379. See also Appeal Brief, para. 377.

Response to the Appeal Brief, para. 214.

Response to the Appeal Brief, para. 215.

Response to the Appeal Brief, para. 215.

Response to the Appeal Brief, para. 215.

Response to the Appeal Brief, paras 216, 218.

Response to the Appeal Brief, para. 216 (emphasis in original omitted).

Response to the Appeal Brief, para. 217 (footnote omitted).

Response to the Appeal Brief, para. 217.

Response to the Appeal Brief, para. 219.

Reply to the Response to the Appeal Brief, para. 41.

Reply to the Response to the Appeal Brief, para. 41.

Conviction Decision, para. 734.

See Čelebić $i$ Trial Judgment, paras 394-395; Aleksovski Trial Judgment, para. 78; Blaškić Trial Judgment, para. 302; Halilović Trial Judgment, para. 73; Kara d žić Trial Judgment, para. 587.

337 See e.g. the measures at the disposal of commanders in Strugar Trial Judgment, para. 374-378; Ha lilo vić Trial Judgment, para. 74; Renzaho Trial Judgment, para. 755; Ka ra d žićTrial Judgment, para. 588.

Appeal Brief, para. 339.

In challenging the Trial Chamber's finding on effective control, Mr Bemba argues, inter alia, that "[b]y ignoring the realities of command in multinational contingents", the Trial Chamber erred (Appeal Brief, para 185). Referring to the $A F R C$ Trial Judgment, he further submits that "[i]n a case involving the temporary transfer of a contingent to assist a loyalist coalition across national boundaries, $[\ldots]$ the traditional indicia of effective control provided in the jurisprudence may not be appropriate or useful" (Appeal Brief, para 180, referring to $A F R C$ Trial Judgment, para. 787). See also Appeal Brief, paras 130, 175-184.

Conviction Decision, para. 732.

Conviction Decision, para. 732.

Conviction Decision, para. 729.

The Trial Chamber found, inter alia, that Mr Bemba had exercised "primary disciplinary authority" (Conviction Decision, para. 703. See also paras 447-449); "ultimate decisionmaking authority" (Conviction Decision, para. 697); "controlled the MLC's funding" (Conviction Decision, para. 697); retained "disciplinary powers over MLC members, including the power to initiate inquiries and establish courtsmartial" (Conviction Decision, para. 697); and "issue[d] the order for the MLC troops to withdraw from the CAR" Conviction Decision, para. 555).

44 Appeal Brief, para. 349, fn. 687, referring to Transcript of 20 March 2012, ICC-01/05-01/08-T-218-Red2-Eng, p. 39, lines 15-19.

5 Transcript of 20 March 2012, ICC-01/05-01/08-T-218-Red2Eng, p. 39, lines 15-19.

6 Conviction Decision, para. 699.

Conviction Decision, para. 731.

Conviction Decision, para. 448.
Appeal Brief, paras 357, 360. See also Mr Bemba's Closing Brief, para. 869.

350 Response to the Appeal Brief, para. 211.

351 Conviction Decision, para. 606, referring to EVD-T-OTP00584/CAR-OTP-0033-0209 at 0209.

352 Conviction Decision, para. 733.

353 Halilović Appeal Judgment, para. 63; OrićAppeal Judgment, para. 177; Strugar Appeal Judgment, paras 232, 236-238, Separate Opinion of Judge Shahabuddeen, para. 7, Joint Dissenting Opinion of Judge Meron and Judge Kwon, para. 11; RUF Trial Judgment, para. 313; Boškoski and Tarču lovski Appeal Judgment, Separate Opinion of Judge Liu Daqun, para. 2; Kaing Guek Eav Trial Judgment, para. 545; Đorđević Trial Judgment, para. 1887; Nuon Chea and Khieu Samphan Trial Judgment, para. 716. See also G. Mettraux, "Breach of a Duty and Consequential Failure to Prevent or to Punish Crimes of Subordinates", The Law of Command Responsibility (Oxford University Press, 2009), p. 229, at p. 255; W.J. Fenrick, "Article 28", in O. Triffterer (ed.), Commentary on the Rome Statute of the International Criminal Court: Observers' Notes, Article by Article (Nomos Verlagsgesellscaft Baden-Baden, 1st ed., 1999), p. 520.

354 Conviction Decision, para. 728.

355 Conviction Decision, para. 728.

356 Appeal Brief, para. 363.

357 Conviction Decision, para. 582.

358 Conviction Decision, para. 604.

359 Conviction Decision, para. 555.

360 Conviction Decision, para. 728.

361 Conviction Decision, para. 720.

362 Conviction Decision, para. 720.

363 Conviction Decision, para. 733.

364 Conviction Decision, para. 449.

365 See supra paras 116-119.

366 See Conviction Decision, para. 461, fn. 1304 regarding Bangui; para. 486, fn. 1408 regarding Bangui; para. 520, fn. 1567 in relation to PK22; para. 525, fn. 1585 regarding Damara; para. 527, fn. 1591 regarding the BossembéléBozoum axis; para. 531, fn. 1607 regarding Sibut; para. 534, fn. 1619 regarding the Bossembélé-Bossangoa axis.

367 See e.g. Conviction Decision, para. 461, fn. 1304 regarding Bangui (EVD-T-OTP-00395/CAR-OTP-0001-0034 at 00480053; EVD-T-OTP-00411/CAR-OTP-0004-1096 at 11021103, 1109, 1121, 1124; EVD-T-OTP-00399/CAR-OTP0004-0343 at 0344; EVD-T-OTP-00401/CAR-OTP-00040409 at 0415, 0419-0423, 0425; EVD-T-OTP-00407/CAROTP-0004-0667 at 0667, 0669-0670, 0672-0674, 0678, 0681-0684, 0690).

368 See article 67 (1) (a) of the Statute; Lubanga Appeal Judgment, paras 118-130.

369 Lubanga Appeal Judgment, para. 129. The Appeals Chamber also found that: " $[\mathrm{t}] \mathrm{o}$ the extent that further information [about the charges] is provided in the course of the trial, this can only go towards assessing whether prejudice caused by the lack of detail of the charges may have been cured".

370 Second Amended Document Containing the Charges, para. 27 (2).

371 Appeal Brief, para. 343. 
372 See supra paras $171-173$.

373 See supra paras 174-175.

374 See supra paras 176-179.

375 See supra paras 180-181.

376 See supra para. 182.

377 See supra paras 183-184.

378 See supra paras 185-188.

379 Conviction Decision, para. 719.

380 This is reflected, inter alia, in article 81 (3) (c) of the Statute.
381 Bemba et al. Conviction Decision, p. 455; Bemba et al. Appeal Judgment, para. 1631.

382 Bemba et al. Sentencing Appeal Judgment, paras 359, 361362.

383 Trial Chamber VII, in the Bemba et al. Sentencing Decision, found that the maximum sentence of imprisonment that it could impose in relation to the offences under article 70 (1) of the Statute of which inter alia Mr Bemba was convicted was five years. The sentence of imprisonment initially imposed by Trial Chamber VII-though reversed by the Appeals Chamber - was one year of imprisonment (Bemba et al. Sentencing Decision, paras 30, p. 99). 